\title{
Observations of glyoxal and formaldehyde as metrics for the anthropogenic impact on rural photochemistry
}

\author{
J. P. DiGangi ${ }^{1, *}$, S. B. Henry ${ }^{1}$, A. Kammrath ${ }^{1,{ }^{* *}}$, E. S. Boyle ${ }^{1}$, L. Kaser ${ }^{2}$, R. Schnitzhofer ${ }^{2}$, M. Graus ${ }^{3,4}$, \\ A. Turnipseed ${ }^{5}$, J-H. Park ${ }^{6}$, R. J. Weber ${ }^{6}$, R. S. Hornbrook ${ }^{5}$, C. A. Cantrell ${ }^{5}$, R. L. Maudlin III ${ }^{5,7, * * *}$, S. Kim ${ }^{5}$, \\ Y. Nakashima ${ }^{8}$, G. M. Wolfe ${ }^{1}$, Y. Kajii ${ }^{8}$, E.C. Apel ${ }^{5}$, A. H. Goldstein ${ }^{6,9}$, A. Guenther ${ }^{5}$, T. Karl ${ }^{5}$, A. Hansel ${ }^{2}$, and \\ F. N. Keutsch ${ }^{1}$ \\ ${ }^{1}$ Department of Chemistry, University of Wisconsin-Madison, Madison, WI, USA \\ ${ }^{2}$ Institute of Ion Physics and Applied Physics, University of Innsbruck, Innsbruck, Austria \\ ${ }^{3}$ Cooperative Institute for Research in Environmental Sciences, University of Colorado, Boulder, CO, USA \\ ${ }^{4}$ Chemical Sciences Division, National Oceanic and Atmospheric Administration, Boulder, CO, USA \\ ${ }^{5}$ Atmospheric Chemistry Division, National Center for Atmospheric Research, Boulder, CO, USA \\ ${ }^{6}$ Department of Environmental Science, Policy, and Management, University of California, Berkeley, CA, USA \\ ${ }^{7}$ Department of Physics, University of Helsinki, Helsinki, Finland \\ ${ }^{8}$ Division of Applied Chemistry, Faculty of Urban Environmental Sciences, Tokyo Metropolitan University, Tokyo, Japan \\ ${ }^{9}$ Department of Civil and Environmental Engineering, University of California, Berkeley, CA, USA \\ * now at: Department of Civil \& Environmental Engineering, Princeton University, Princeton, NJ, USA \\ ***now at: Kimberly Clark Corporation, Neenah, WI, USA \\ **** now at: Department of Atmospheric and Oceanic Sciences, University of Colorado, Boulder, CO, USA
}

Correspondence to: F. N. Keutsch (keutsch@chem.wisc.edu)

Received: 27 January 2012 - Published in Atmos. Chem. Phys. Discuss.: 24 February 2012

Revised: 24 August 2012 - Accepted: 19 September 2012 - Published: 22 October 2012

\begin{abstract}
We present simultaneous fast, in-situ measurements of formaldehyde and glyoxal from two rural campaigns, BEARPEX 2009 and BEACHON-ROCS, both located in Pinus Ponderosa forests with emissions dominated by biogenic volatile organic compounds (VOCs). Despite considerable variability in the formaldehyde and glyoxal concentrations, the ratio of glyoxal to formaldehyde, $\mathrm{R}_{\mathrm{GF}}$, displayed a very regular diurnal cycle over nearly 2 weeks of measurements. The only deviations in $\mathrm{R}_{\mathrm{GF}}$ were toward higher values and were the result of a biomass burning event during BEARPEX 2009 and very fresh anthropogenic influence during BEACHON-ROCS. Other rapid changes in glyoxal and formaldehyde concentrations have hardly any affect on $\mathrm{R}_{\mathrm{GF}}$ and could reflect transitions between low and high NO regimes. The trend of increased $R_{\mathrm{GF}}$ from both anthropogenic reactive VOC mixtures and biomass burning compared to biogenic reactive VOC mixtures is robust due to the short timescales over which the observed changes in $\mathrm{R}_{\mathrm{GF}}$ occurred. Satellite retrievals, which suggest higher $\mathrm{R}_{\mathrm{GF}}$
\end{abstract}

for biogenic areas, are in contrast to our observed trends. It remains important to address this discrepancy, especially in view of the importance of satellite retrievals and in situ measurements for model comparison. In addition, we propose that $\mathrm{R}_{\mathrm{GF}}$ represents a useful metric for biogenic or anthropogenic reactive VOC mixtures and, in combination with absolute concentrations of glyoxal and formaldehyde, furthermore represents a useful metric for the extent of anthropogenic influence on overall reactive VOC processing via $\mathrm{NO}_{\mathrm{x}}$. In particular, $\mathrm{R}_{\mathrm{GF}}$ yields information about not simply the VOCs dominating reactivity in an airmass, but the VOC processing itself that is directly coupled to ozone and secondary organic aerosol production.

\section{Introduction}

The oxidation of volatile organic compounds (VOCs) is directly coupled to the production of tropospheric ozone, a 
major atmospheric pollutant correlated with increased incidences of poor respiratory health, crop damage (Mauzerall and Wang, 2001; Stieb et al., 2000), and production of secondary organic aerosol (Dockery et al., 1993; Laden et al., 2000; Ostro, 1993). Production of tropospheric ozone is dependent on VOCs in two ways: the composition of the reactive mixture of VOCs in the atmosphere and the oxidation pathways and mechanisms of these VOCs. Due to the wide variety of VOCs in the atmosphere, both explicit measurement of the VOC mixture and a quantitative understanding of the oxidation pathways of the VOC mixture are challenging. Observations of oxidation products are fundamental to testing and improving our understanding of VOC oxidation. Measurements of oxidation products specific to only one VOC (e.g. MVK from isoprene oxidation) are valuable as are measurements of species that are produced from oxidation of many VOCs (e.g. formaldehyde, a general VOC oxidation tracer). By comparing general VOC oxidation tracers that are produced from both anthropogenic and biogenic VOCs (AVOCs/BVOCs, respectively), but whose relative yields vary between AVOCs and BVOCs, it could be possible to determine which type of VOC contributes more to the reactivity of a given air mass. Through observation of such oxidation products, we may obtain a metric to identify changes in the overall reactive VOC mixture.

Formaldehyde (HCHO) and glyoxal (Gly, CHOCHO) are ubiquitous oxidized VOCs (OVOCs) formed as intermediates in the VOC- $\mathrm{HO}_{\mathrm{x}}-\mathrm{NO}_{\mathrm{x}}$ cycle $\left(\mathrm{HO}_{\mathrm{x}}=\mathrm{HO}+\mathrm{HO}_{2}, \mathrm{NO}_{\mathrm{x}}\right.$ $=\mathrm{NO}+\mathrm{NO}_{2}$ ), the catalytic photochemical cycle responsible for VOC oxidation in the atmosphere (Fried et al., 1997; Lee et al., 1998; Tan et al., 2001). HCHO is produced in the oxidation of nearly all VOCs and is often used as a tracer of overall VOC oxidation. It is also directly emitted from various sources (DiGangi et al., 2011; Garcia et al., 2006), but most of the budget derives from photochemical production (Luecken et al., 2012). Gly is similarly formed from the oxidation of many VOCs, such as alkene and aromatic species. Additionally, Gly has virtually no primary sources (Volkamer et al., 2005), except from biomass burning (Fu et al., 2008; Hays et al., 2002; McDonald et al., 2000), which makes it an excellent measure of the rate of photochemical oxidation (Garcia et al., 2006; Huisman et al., 2011). Both Gly and HCHO have similar midday lifetimes on the order of a few hours, driven by photolysis, reaction with $\mathrm{OH}$ and, near the surface, deposition (Atkinson, 2000).

Due to these differences in sources and similarity in sinks, the $\mathrm{Gly} / \mathrm{HCHO}$ ratio $\left(R_{\mathrm{GF}}\right)$ has been proposed as a tracer of changes in the atmospheric VOC mixture. Satellite retrievals and modeling studies suggest higher values of $R_{\mathrm{GF}}$ (4-6\%) in biogenically-influenced regions and lower values $(<4 \%)$ in anthropogenically-influenced regions (Myriokefalitakis et al., 2008; Vrekoussis et al., 2009, 2010; Wittrock et al., 2006). However, there have been no reported investigations of using $R_{\mathrm{GF}}$ as a tracer of local VOC oxidation or tracer of the reactive VOC composition. Additionally, biogenically-dominated regions can differ in reactive VOC composition due to different relative emissions of BVOC species. In this work, we present simultaneous, fast ( $<1 \mathrm{~min})$, online, in-situ observations of both Gly and HCHO during two rural field intensives in different Pinus Ponderosa forests, BEARPEX 2009 and BEACHON-ROCS. Furthermore, we compare and discuss $R_{\mathrm{GF}}$ values between these campaigns and with respect to $R_{\mathrm{GF}}$ reported in the literature. Finally, we discuss multiple events during these campaigns in the context of the fate of alkyl peroxy radicals $\left(\mathrm{RO}_{2}\right)$ as well as the role of anthropogenic influence on rural regions through the influence of anthropogenic VOCs and $\mathrm{NO}_{\mathrm{x}}$.

\section{Experimental}

\subsection{Site information}

The Biosphere Effects on AeRosols and Photochemistry EXperiment (BEARPEX) 2009 took place in a Sierra Pacific Industries Pinus Ponderosa plantation (canopy height $\approx 9 \mathrm{~m}$; leaf area index $(\mathrm{LAI}) \approx 3.7)$ in the Sierra Nevada Mountains $\left(38^{\circ} 53^{\prime} 42.9^{\prime \prime} \mathrm{N}, 120^{\circ} 37^{\prime} 59.7^{\prime \prime} \mathrm{W}, 1315 \mathrm{~m}\right)$ near the Blodgett Forest Research Station from 15 June-31 July 2009. This site has been described in detail elsewhere (Dillon et al., 2002; Dreyfus et al., 2002; Goldstein et al., 2000) and exhibits a regular diurnal wind profile driven by the mountain anabatic/katabatic winds. Local emissions are primarily 2-methyl-3-buten-2-ol (MBO) and monoterpenes (MT) with diurnally consistent midday advection of isoprene and oxidation products (Dreyfus et al., 2002) and late afternoon/evening arrival of the Sacramento urban plume (Dillon et al., 2002). Additionally, this site had a significant understory with an estimated height of $2 \mathrm{~m}$ and an estimated LAI of $\sim 1.9$ (Wolfe and Thornton, 2011).

The Bio-hydro-atmosphere interactions of Energy, Aerosols, Carbon, $\mathrm{H}_{2} \mathrm{O}$, Organics \& Nitrogen-Rocky Mountain Organic Carbon Study (BEACHON-ROCS) 2010 took place in the Manitou Experimental Forest (MEF, $39^{\circ} 06^{\prime} 02^{\prime \prime} \mathrm{N}, 105^{\circ} 06^{\prime} 05^{\prime \prime} \mathrm{W}, 2286 \mathrm{~m}$ ) from 1-31 August 2010. MEF is a Central Rocky Mountains Pinus Ponderosa woodland (canopy height $\approx 18.5 \mathrm{~m} ; \mathrm{LAI} \approx 1.9$ ) located $\sim 40$ $\mathrm{km}$ northwest of Colorado Springs, $\mathrm{CO}$ and $\sim 70 \mathrm{~km}$ south of Denver, CO. This site has been described previously (DiGangi et al., 2011; Kim et al., 2010) and exhibited minimal undergrowth and predominantly biogenic-influenced air.

\subsection{Gly and HCHO measurements}

Gly and HCHO measurements were obtained by two different instruments: the Madison-Laser Induced Phosphorescence (Mad-LIP) instrument and the Madison Fiber LaserInduced Fluorescence (FILIF) instrument, respectively. Details for these instruments can be found elsewhere (DiGangi et al., 2011; Hottle et al., 2009; Huisman et al., 2008) but will be briefly mentioned here. The Mad-LIP instrument uses 
a $440 \mathrm{~nm}$ narrow-bandwidth $(\sim 0.06 \mathrm{~nm}), \mathrm{Nd}$ :YAG-pumped, doubled Ti:Sapphire laser (Photonics Industries, TU series), and FILIF uses a $353 \mathrm{~nm}$ narrow-bandwidth pulsed fiber laser (NovaWave Technologies, TFL Series). The lasers are used to excite either Gly or HCHO photoluminescence in the center of a 32-pass White-type multipass cell. Laser scatter was minimized by the presence of carbon black-coated baffling as well as a light trap opposite the detector. Photoluminescence from the analytes was collimated, passed through an optical filter (HCHO: $390 \mathrm{~nm}$ longpass, Gly: $520 \pm 10 \mathrm{~nm}$ bandpass), and then focused onto the entire active area of a photon-counting photomultiplier tube. The photoluminescence signal was electronically gated to optimize detection of the photoluminescence signal and reduce observed laser scatter, thus maximizing signal/noise. Since this electronic gating also preferentially detected photons only in a specific time window after the laser pulse, only photons with the lifetime of the luminescence were observed, increasing selectivity. Any remaining background was subtracted by dithering the laser periodically between near wavelengths of high and low absorption cross-section. The difference between these two signals is proportional to the analyte concentration.

Gly and HCHO gradients were measured during BEARPEX 2009 by alternately sampling from four $\sim 30 \mathrm{~m}$ $3 / 8^{\prime \prime}$ PTFE Teflon inlets at heights of $17.8 \mathrm{~m}, 8.7 \mathrm{~m}, 3.3 \mathrm{~m}$, and $2.4 \mathrm{~m}$, with the exception of the use of PFA for the $17.8 \mathrm{~m}$ HCHO inlet. During BEACHON-ROCS, gradients measured by alternately sampling from four $\sim 30 \mathrm{~m} 3 / 8^{\prime \prime}$ ID PTFE (Gly) or PFA (HCHO) Teflon inlets placed at heights of $25.1 \mathrm{~m}, 17.7 \mathrm{~m}, 8.5 \mathrm{~m}$, and $1.6 \mathrm{~m}$. Inlet comparison testing was performed for both instruments and observed no detectable inlet artifacts (DiGangi, 2012). Mad LIP calibrations were performed weekly using a gas standard quantified in the field via cavity ringdown spectroscopy as described by Huisman et al. (Huisman et al., 2008), and weekly FILIF calibrations were performed using an FTIR cross-calibrated permeation source as described by DiGangi et al. (DiGangi et al., 2011). The Mad-LIP instrument detection limit $(3 \sigma)$ for both campaigns was $16 \mathrm{pptv}$ in $1 \mathrm{~s}$, while the FILIF detection limit was $1 \mathrm{ppbv}$ in $1 \mathrm{~s}$ during BEARPEX 2009 and $300 \mathrm{pptv}$ in $1 \mathrm{~s}$ during BEACHONROCS. Calibration uncertainties (accuracies) were $20 \%$ for Gly and $30 \%$ for HCHO during both campaigns. Sixty second median precisions for Gly measurements were $8.9 \%$ and $11.5 \%$ during BEARPEX and BEACHON-ROCS, respectively, while thirty second precisions for HCHO measurements were $11.1 \%$ and $0.37 \%$ during BEARPEX and BEACHON-ROCS, respectively. This results in an $R_{\mathrm{GF}}$ accuracy of $36 \%$ and $R_{\mathrm{GF}}$ median precisions of $15.6 \%$ and $11.6 \%$ during BEARPEX and BEACHON-ROCS, respectively.

\subsection{Other measurements}

Details of the meteorological measurements during BEARPEX 2009 can be found elsewhere (Goldstein et al., 2000). Carbon monoxide (CO) was measured via a gas correlation infrared spectrometer (Thermo Environmental Instruments, Model 48C). Concentrations of benzene $\left(\mathrm{C}_{6} \mathrm{H}_{7}^{+}\right)$, acetonitrile $\left(\mathrm{C}_{2} \mathrm{H}_{4} \mathrm{~N}^{+}\right)$, the sum of 2-methyl3-buten-2-ol (MBO) and isoprene $\left(\mathrm{C}_{5} \mathrm{H}_{11} \mathrm{O}^{+}\right.$and $\mathrm{C}_{5} \mathrm{H}_{9}^{+}$, hereafter referred to as $\mathrm{MBO}+$ Isoprene), and the sum of BVOC oxidation products such as methylvinyl ketone and methacrolein $\left(\mathrm{C}_{4} \mathrm{H}_{7} \mathrm{O}^{+}\right)$were measured via quadrupole proton transfer reaction-mass spectrometry (PTR-MS).

Details of the additional measurements during BEACHON-ROCS can also be found elsewhere (DiGangi et al., 2011). Benzene $\left(\mathrm{C}_{6} \mathrm{H}_{7}^{+}, \mathrm{m} / \mathrm{z}\right.$ 79.055), acetonitrile $\left(\mathrm{C}_{2} \mathrm{H}_{4} \mathrm{~N}^{+}, \mathrm{m} / \mathrm{z}\right.$ 42.035), MBO+Isoprene $\left(\mathrm{C}_{5} \mathrm{H}_{11} \mathrm{O}^{+}\right.$\& $\mathrm{C}_{5} \mathrm{H}_{9}^{+}, 87.081 \&$ 69.070), $\mathrm{C}_{4} \mathrm{H}_{7} \mathrm{O}^{+}(\mathrm{m} / z$ 71.050), and $\mathrm{C}_{6} \mathrm{H}_{7} \mathrm{O}^{+}(\mathrm{m} / z$ 95.050, likely corresponding to phenol) concentrations were measured via proton transfer reaction-time of flight-mass spectrometry (PTR-TOF-MS) (Graus et al., 2010; Jordan et al., 2009; Ruuskanen et al., 2011). Further details about the PTR-TOF-MS measurements during this field campaign can be found in Kaser et al. (2012) and Müller et al. (2010). Additional VOCs, including isoprene, toluene, and benzene, as well as the toluene:benzene ratio $\left(\mathrm{R}_{\mathrm{TB}}\right)$, were measured with the Total Organic Gas Analyzer (TOGA) (Apel et al., 2010, 2003; Hornbrook et al., 2011a). Nitrogen oxide (NO) was measured via chemiluminescence (Eco Physics AG, Model CLD-88Y). $\mathrm{OH}, \mathrm{HO}_{2}$ and $\mathrm{RO}_{2}$ were measured by the NCAR chemical ionization mass spectrometers (CIMS) (Hornbrook et al., 2011b; Mauldin et al., 1999).

\section{Observations}

Figure 1 shows the diurnal profiles of Gly and $\mathrm{HCHO}$ concentrations, Gly:HCHO ratios $\left(R_{\mathrm{GF}}\right)$, and wind direction for both sites, while Figs. S1 and S2 show Gly and HCHO concentrations for the entirety of each campaign. Gly and HCHO concentrations at both sites (Fig. 1c-f) exhibited a moderately variable diurnal profile, with typical concentration maxima in the early evening and minima around sunrise. Average Gly and HCHO concentrations were significantly higher during BEARPEX 2009 than during BEACHON-ROCS, which concur with higher $\mathrm{OH}$ reactivity during the BEARPEX 2009 campaign (Fig. S3e-f). $R_{\mathrm{GF}}$ during each campaign (Fig. 1a and b) showed a remarkably consistent diurnal profile peaking at midday that is nearly independent of Gly or $\mathrm{HCHO}$ concentration changes. BEACHON-ROCS $R_{\mathrm{GF}}$ were typically higher (on average, 32\%) than BEARPEX 2009 $R_{\mathrm{GF}}$ and also exhibited a much stronger diurnal cycle than BEARPEX $2009 R_{\mathrm{GF}}$. Box model simulations based on the 

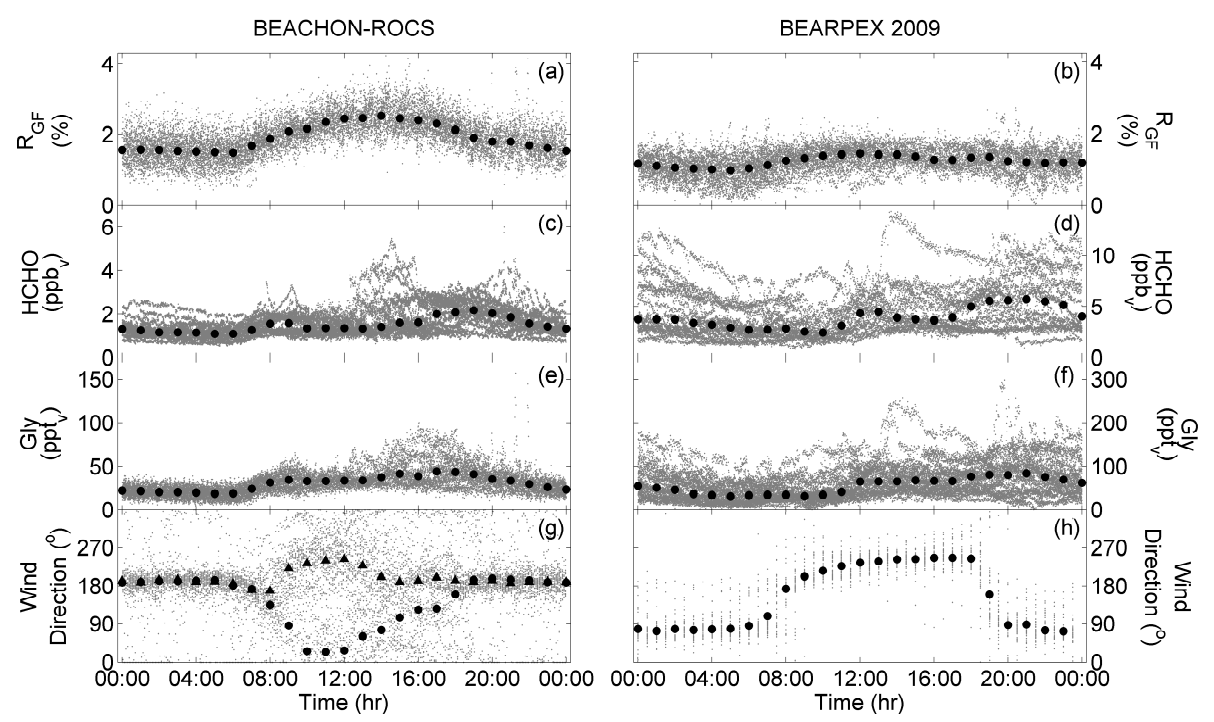

Fig. 1. Diurnal profiles of $R_{\mathrm{GF}}$, HCHO, Gly, and wind direction during BEACHON-ROCS and BEARPEX 2009. Grey dots represent individual $\sim 30 \mathrm{~s}$ data points and black dots represent the $1 \mathrm{~h}$ diurnal binned medians. Note that the Gly and HCHO y-axes are not the same between the two campaigns. The different symbols in the bottom left panel denote the two dominant diurnal wind profiles for that campaign, with triangles indicating the more dominant $(\sim 60 \%)$ southwesterly wind direction and circles indicating the less dominant $(\sim 40 \%)$ northeasterly wind direction.

Table 1. Percent increases for Gly, $\mathrm{HCHO}, R_{\mathrm{GF}}$, and other species for each transport event. Note that the values listed for $R_{\mathrm{GF}}$ are the relative increases, not absolute changes in values.

\begin{tabular}{ccccccc}
\hline Event & $\begin{array}{c}\text { MFI } \\
\text { (Day 1) }\end{array}$ & $\begin{array}{c}\text { MFI } \\
\text { (Day 2) }\end{array}$ & BN1 & BN2 & $\begin{array}{c}\text { BN3 } \\
\text { (afternoon) }\end{array}$ & $\begin{array}{c}\text { BN3 } \\
\text { (evening) }\end{array}$ \\
\hline Event Time & $18: 00-19: 30$ & $12: 30-14: 30$ & $16: 30-18: 00$ & $14: 00-15: 30$ & $13: 00-14: 00$ & $20: 00-21: 15$ \\
Gly & $280 \%$ & $140 \%$ & $94 \%$ & $120 \%$ & - & $380 \%$ \\
HCHO & $110 \%$ & $120 \%$ & $160 \%$ & $54 \%$ & $250 \%$ & $67 \%$ \\
$R_{\text {GF }}$ & $79 \%$ & $18 \%$ & $-18 \%$ & $3 \%$ & - & $190 \%$ \\
MBO+Isoprene & $-58 \%$ & $-18 \%$ & $-2 \%$ & $7 \%$ & $-12 \%$ & $84 \%$ \\
m/z 71 & $6 \%$ & $77 \%$ & $42 \%$ & $200 \%$ & $320 \%$ & $120 \%$ \\
Benzene & $280 \%$ & $180 \%$ & $150 \%$ & $320 \%$ & $260 \%$ & $230 \%$ \\
Acetonitrile & $150 \%$ & $100 \%$ & $4 \%$ & $20 \%$ & $12 \%$ & $3 \%$ \\
CO & $110 \%$ & $120 \%$ & $30 \%$ & $20 \%$ & $50 \%$ & $<10 \%$ \\
\hline
\end{tabular}

University of Leeds Master Chemical Mechanism (Jenkin et al., 1997; Saunders et al., 2003) updated with a recently reported direct Gly yield from isoprene (Galloway et al., 2011b; Wolfe and Thornton, 2011) predict higher $R_{\mathrm{GF}}$ for $\mathrm{MBO}$ oxidation than for isoprene oxidation for NO concentrations similar to those during these campaigns, which is consistent with the high observed Gly yields from MBO oxidation (Chan et al., 2009). As isoprene is a ubiquitously emitted VOC present during BEARPEX 2009 but is present in much lower relative quantities during BEACHON-ROCS, this would chemically suggest that $R_{\mathrm{GF}}$ should be higher during BEACHON-ROCS compared to during BEARPEX, in agreement with our observed trends.

The diurnal wind direction profile during BEARPEX 2009 (Fig. 1h) was very consistent, with wind from the east overnight and the west during the day. During BEACHONROCS, the diurnal wind direction profile (Fig. 1g) was best represented by two regimes. Winds consistently originated from the south at night, while during the day the dominant wind direction was either southwesterly $(\sim 60 \%)$ or northeasterly $(\sim 40 \%)$. Diurnal Gly and HCHO concentrations were higher in the afternoon for the northeasterly regime, while $R_{\mathrm{GF}}$ was similar between the regimes (Fig. S4). Thus, the consistent lower nighttime $R_{\mathrm{GF}}$ is possibly due to either a buildup of directly-emitted HCHO and/or terpene oxidation in the stable nocturnal boundary layer, or preferential dry deposition of Gly over HCHO, though current data is insufficient to verify either of these conclusions.

During both campaigns, there existed a number of what we will refer to as transport events, indicated by a sharp 


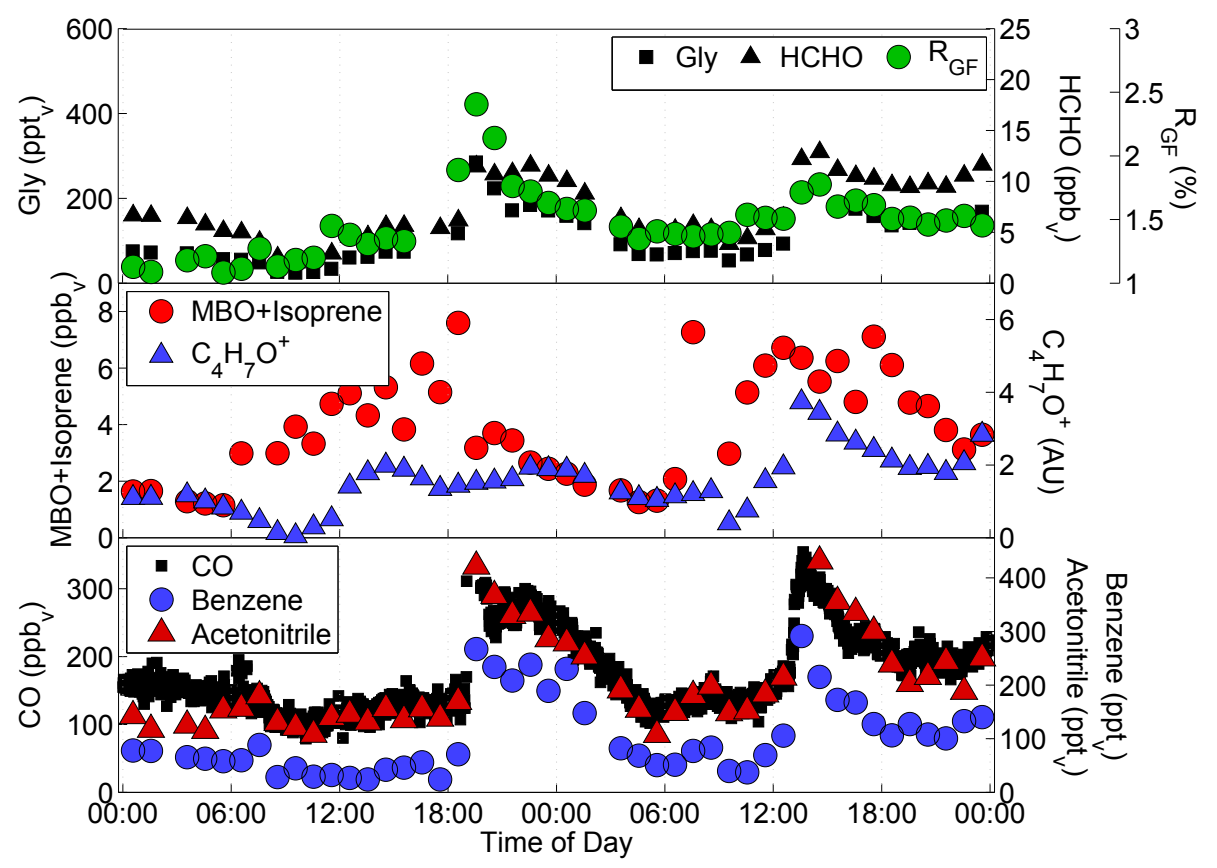

Fig. 2. Gly, $\mathrm{HCHO}, R_{\mathrm{GF}}$ and other tracer species during the two days of the MFI (DOY $\left.197 \& 198\right)$. Gly, HCHO, and $R_{\mathrm{GF}}$ are shown as 30 min binned averages ( \pm 15 min each half hour), whereas other species are shown at full resolution. Data for $\mathrm{MBO}_{+} \mathrm{Isoprene}_{\mathrm{S}} \mathrm{C}_{4} \mathrm{H}_{7} \mathrm{O}^{+}$, benzene, and acetonitrile were measured via PTR-MS.

transition from low to high (or vice-versa) concentrations of many species. These events during BEACHON-ROCS were observed as intermittent but regular occurrences, while only a two-day series of events occurred during BEARPEX 2009. We will use a selection of these events to probe the chemistry driving the behavior of $R_{\mathrm{GF}}$.

\subsection{BEARPEX 2009 16-17 July 2009: Mammoth Fire Incident (MFI)}

During BEARPEX 2009, only one event, consisting of two consecutive days (16-17 July, 2009), was observed that showed deviation from the regular diurnal trends in HCHO, Gly and $R_{\mathrm{GF}}$. The event corresponds to the Mammoth Fire Incident (MFI) which occurred in the American River Canyon $\left(38.93^{\circ} \mathrm{N}, 120.99^{\circ} \mathrm{W}, \sim 400 \mathrm{~m}\right)$ east of Auburn, CA. The MFI began on 16 July, 2009 at 14:33 (all times local, PST) and was reported contained on 18 July 2009 at 19:30 (http://bof.fire.ca.gov/incidents/incidents_details_info? incident_id=340).

Figure 2 shows concentrations of Gly, $\mathrm{HCHO}, R_{\mathrm{GF}}$, and other relevant species during the MFI events, while Figure S5 also shows additional parameters (RH, PAR, wind direction, $\mathrm{u}_{*}$ ) and Figure S12a shows the precision for the contrasting features. The morning and afternoon of 16 July had Gly and HCHO concentrations and $R_{\mathrm{GF}}$ typical for BEARPEX 2009. At $\sim 19: 00$, there was a sharp increase in $R_{\mathrm{GF}}$, as well as in concentrations of Gly, HCHO, benzene, acetonitrile, and CO (see Table 1), referred to as the first MFI event. The timing of this first MFI event is consistent with the arrival of the plume from the MFI site modeled by HYSPLIT forward trajectories (Fig. S5) (Draxler and Rolph, 2011; Rolph, 2011), which predict arrival of the plume at the BEARPEX 2009 site between $\sim 18: 30$ and $\sim 19: 30$. $R_{\mathrm{GF}}$, Gly, HCHO, benzene, acetonitrile, and $\mathrm{CO}$ concentrations all exhibited similar decays as the evening progressed. No sharp rise was observed in oxidation products specific to BVOCs, as judged by $\mathrm{C}_{4} \mathrm{H}_{7} \mathrm{O}^{+}$, while $\mathrm{MBO}+$ Isoprene (representative of daytime BVOC emissions) followed the campaign-averaged evening decrease in concentration. The coincidence of the rises in acetonitrile, a tracer of biomass burning (Holzinger et al., 1999, 2005), and CO, a tracer of incomplete combustion (Khalil and Rasmussen, 1988), with the rise in Gly, HCHO and $R_{\mathrm{GF}}$ is consistent with influence from biomass burning, such as the MFI. This rise in $R_{\mathrm{GF}}$ is noteworthy, as it was the only time during the 20 days of Gly and HCHO measurements at BEARPEX 2009 that showed a pronounced and rapid change in $R_{\mathrm{GF}}$. These observations demonstrate that $R_{\mathrm{GF}}$ was clearly enhanced due to a biomass-burning plume. This effect is consistent with satellite retrievals (Vrekoussis et al., 2010) and can likely be attributed to differing primary emission rates of Gly and $\mathrm{HCHO}$ from the burning event and/or photochemical processing of biomass burning emissions with relatively short lifetimes $(<3 \mathrm{~h})$.

On 17 July, there was a second sharp increase in Gly, $\mathrm{HCHO}$, benzene, acetonitrile, and $\mathrm{CO}$ concentrations at $\sim$ 13:20, consistent with a HYSPLIT predicted arrival time of the MFI plume (Fig. S7) (Draxler and Rolph, 2011; Rolph, 


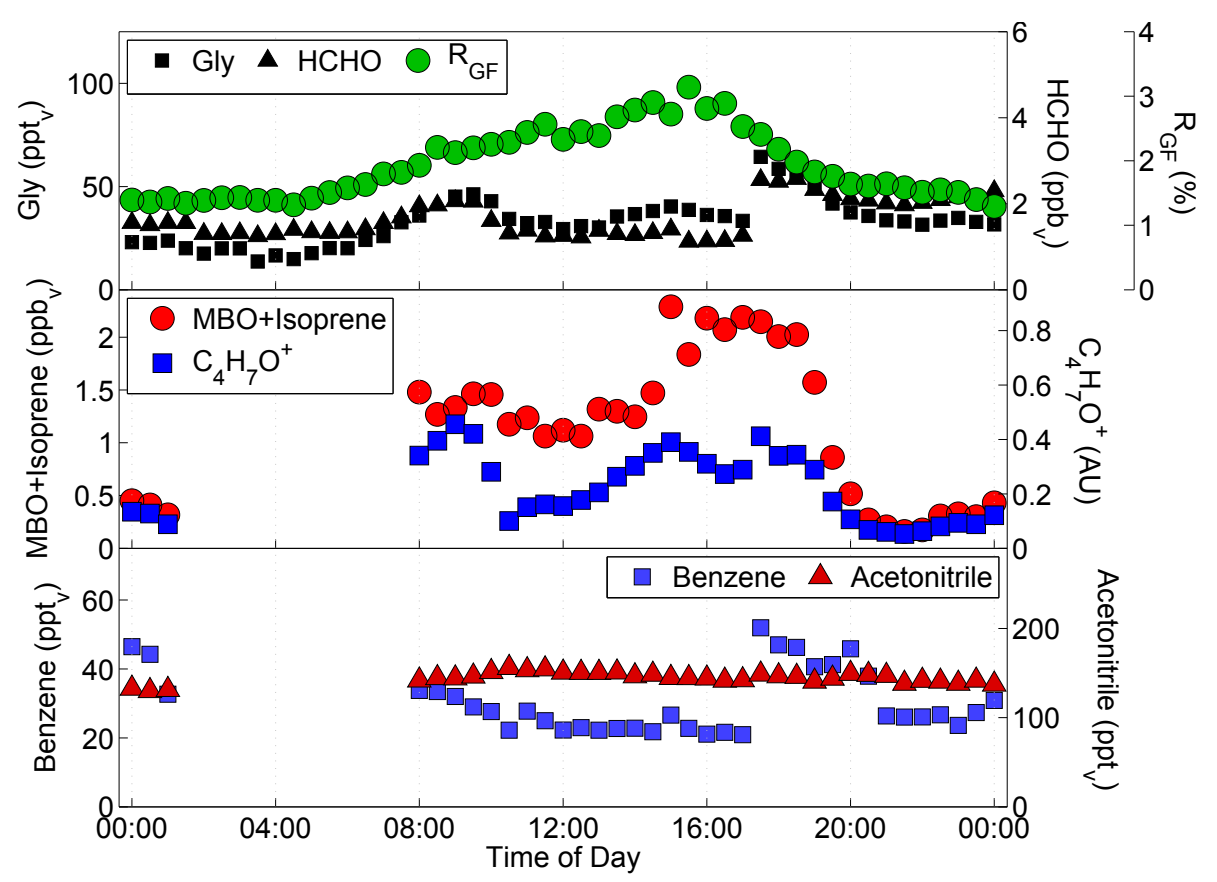

Fig. 3. Gly, $\mathrm{HCHO}, R_{\mathrm{GF}}$ and other tracer species during day BN1 (DOY 230). Gly, HCHO, and $R_{\mathrm{GF}}$ are shown as 30 min binned averages ( \pm 15 min each half hour), whereas other species are shown at full resolution. Data for MBO+Isoprene, $\mathrm{C}_{4} \mathrm{H}_{7} \mathrm{O}^{+}$, benzene, and acetonitrile were measured via PTR-TOF-MS.

2011) of 13:15-13:45. This will be referred to as the second MFI event. Although both HCHO and Gly strongly increased compared to the rest of the campaign, the small increase in $R_{\mathrm{GF}}$ of $18 \%$ was not atypical for BEARPEX 2009 (see Fig. 1). This appears inconsistent with the previous day as the increases in acetonitrile were very similar between the two plume arrivals (Table 1), suggesting $R_{\mathrm{GF}}$ should have risen as well due to biomass burning influence. Additionally, HYSPLIT trajectory models (Fig. S6) predict that the MFI plumes on the two days should have roughly the same age $(\sim 3 \mathrm{~h})$, which is comparable to the lifetime of Gly and $\mathrm{HCHO}$ at that time. In contrast to the previous evening, the arrival of the MFI plume coincided closely with the arrival of isoprene at the measurement site from a band of oak trees to the west, indicated by the significant increases in $\mathrm{C}_{4} \mathrm{H}_{7} \mathrm{O}^{+}$ during the second MFI event, which makes it difficult to discern the influences of the isoprene vs. the biomass burning plume. However, since no other isoprene plume yielded Gly and $\mathrm{HCHO}$ concentrations as high as during this day and combined with the large concentrations of acetonitrile, it is clear that biomass burning can be a significant influence.

Overall, the MFI events show that biomass burning can influence $R_{\mathrm{GF}}$. However, this influence may be dependent on environmental factors, including flaming vs. smoldering phases, which have been shown to exhibit substantial differences in VOC formation rates (Andreae and Merlet, 2001; Koppmann et al., 2005). Acetonitrile concentrations from the MFI plume for the two days are quite similar, but $R_{\mathrm{GF}}$ is very different. This may point to differences in the emission from a biomass burning event as it evolves, as the plume on the first day was from the freshly-started fire while the plume on the second day was when the fire was more than a day old. Additionally, the biomass burning plume arrived late on the first day, at which time the lifetime of Gly and HCHO was much longer than at midday. This is compared to the earlier arrival of the plume on the second day, near midday and simultaneous with the second MFI event. It is possible that the shorter lifetime during the first day resulted in a stronger influence of Gly and HCHO from the biomass burning event at the site.

\subsection{BEACHON-ROCS 18 August 2010 (BN1)}

On 18 August during BEACHON-ROCS, which we refer to as day BN1, sharp changes in Gly and HCHO concentrations were observed (Figs. 3, S8, S12b). In the early morning, concentrations of Gly, $\mathrm{HCHO}$, and particularly $\mathrm{C}_{4} \mathrm{H}_{7} \mathrm{O}^{+}$continuously rose. This was coincident with the onset of photochemistry, BVOC emissions (indicated by the increase in concentration of $\mathrm{MBO}+$ Isoprene), and vertical mixing (estimated by $\mathrm{u}^{*}$ ) expected at this time of day. At $\sim 09: 30$, a sudden shift in wind direction from south to northeast occurred, accompanied by a fast drop in OVOC concentrations (Gly, $\mathrm{HCHO}$, and $\mathrm{C}_{4} \mathrm{H}_{7} \mathrm{O}^{+}$) and only a small decrease in $\mathrm{MBO}+$ Isoprene and benzene concentrations. This will be referred to as the BN1 morning event. Acetonitrile concentration remained constant, implying that they were already 


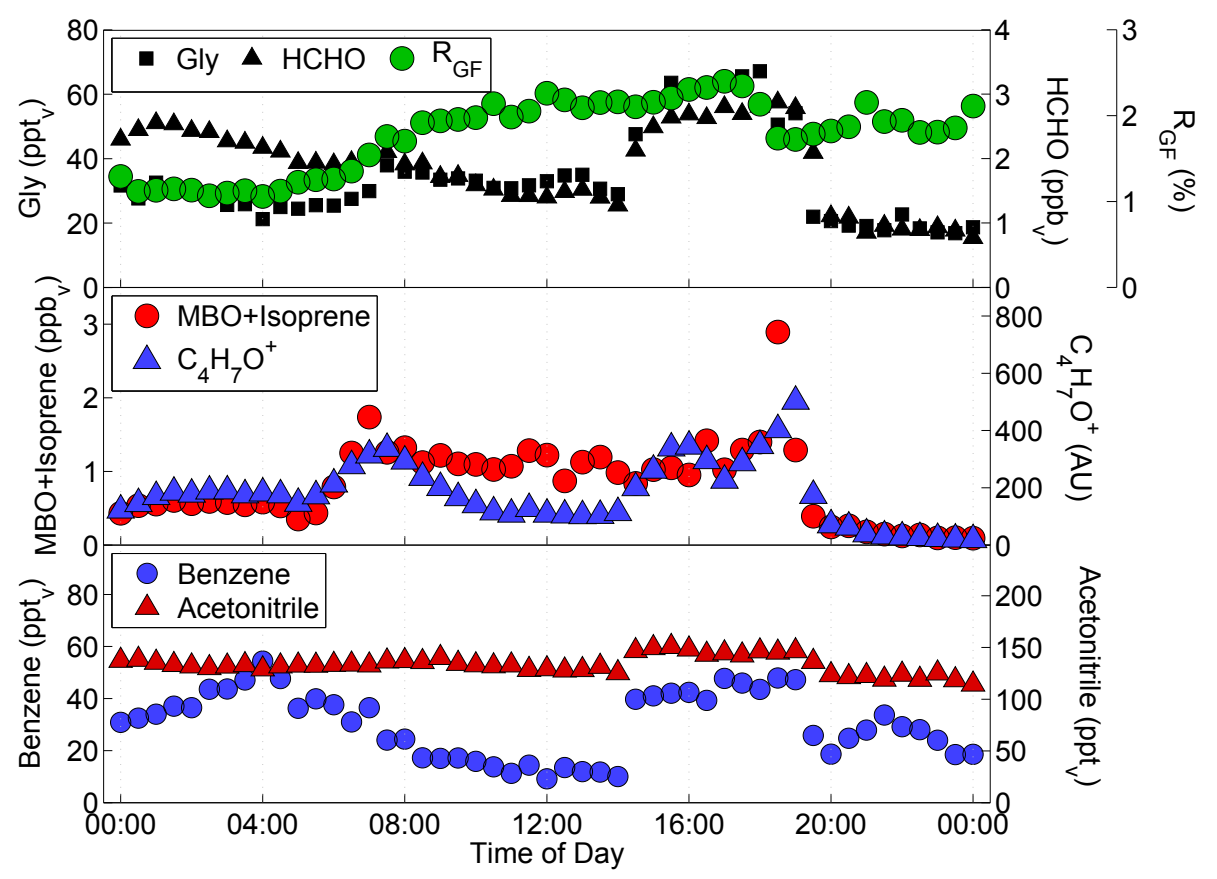

Fig. 4. Gly, $\mathrm{HCHO}, R_{\mathrm{GF}}$ and other tracer species during day BN2 (DOY 231). Gly, HCHO, and $R_{\mathrm{GF}}$ are shown as 30 min binned averages ( $\pm 15 \mathrm{~min}$ each half hour), whereas other species are shown at full resolution. Data for $\mathrm{MBO}+\mathrm{Isoprene}, \mathrm{C}_{4} \mathrm{H}_{7} \mathrm{O}^{+}$, benzene, and acetonitrile were measured via PTR-TOF-MS.

at/near the regional background. Constant MBO+Isoprene concentrations, concurrent with a much larger decrease $(\sim 50 \%)$ in Gly and with near constant $\mathrm{OH}$ concentrations, imply a shift from a more photochemically-aged airmass to one that is less aged, at least in the presence of NO. $R_{\mathrm{GF}}$ shows no discontinuity at this time, which demonstrates that $R_{\mathrm{GF}}$ is insensitive to the extent of airmass processing.

In the afternoon, $R_{\mathrm{GF}}$ continued its regular diurnal increase until the wind direction shifted to the south at $\sim 15: 00$, after which the ratio began to slowly decrease following the average diurnal $R_{\mathrm{GF}}$ pattern. At $\sim 17: 00$, both Gly and HCHO concentrations, which had been nearly level all afternoon, roughly doubled within a few minutes. This will be referred to as the BN1 afternoon event. This fast rise in Gly and $\mathrm{HCHO}$ was accompanied by a fast rise in benzene concentrations, a rise in $\mathrm{C}_{4} \mathrm{H}_{7} \mathrm{O}^{+}$, and no significant change in $\mathrm{MBO}+$ Isoprene or acetonitrile (see Table 1 for values). The trend in many of these tracers was quite similar to those during the MFI events at BEARPEX 2009, with the exceptions of acetonitrile and $R_{\mathrm{GF}}$. $R_{\mathrm{GF}}$ did not only lack an increase, but it in fact continued decreasing on its normal diurnal trend. The lack of change in acetonitrile concentrations with rising benzene concentrations implies that this event arose from anthropogenic influence, rather than biomass burning as during the MFI events, as biogenic emission of benzene is minimal. Despite this noticeable increase in anthropogenic influence and sizable increases in both Gly and HCHO concentrations, $R_{\mathrm{GF}}$ was unaffected. This likely arises from the fact that the same BVOCs still dominate the site's reactive VOC mixture, and the rise in benzene, a VOC with a long lifetime on hourly timescales, likely indicates increased anthropogenic influence via NO rather than via reactive anthropogenic VOCs. Combined with the lack of discontinuity in $R_{\mathrm{GF}}$ during the BN1 morning event, this suggests that $R_{\mathrm{GF}}$ is independent of these changes in $\mathrm{RO}_{2}$ fate regime.

\subsection{BEACHON-ROCS 19 August 2010 (BN2)}

Figure 4 shows another day, referred to as day BN2, with similar sharp Gly and HCHO changes, while Figure S9 shows additional metrics and Figure S12c shows the precision for the contrasting features. The morning had a similar rise in MBO+Isoprene and OVOC concentrations as the morning of BN1. However, there was no morning event as with BN1, as Gly and HCHO increased only slightly. The enhanced morning concentrations slowly decreased as vertical mixing increased. $R_{\mathrm{GF}}$ exhibited a morning profile very similar to that during $\mathrm{BN} 1$, despite these differing conditions. At $\sim 14: 30$, Gly, HCHO, and benzene once again rose very sharply, whereas there was no discernible change in $\mathrm{MBO}+$ Isoprene or acetonitrile and $\mathrm{C}_{4} \mathrm{H}_{7} \mathrm{O}^{+}$also rose considerably (see Table 1). This will be referred to as the $\mathrm{BN} 2$ afternoon event. Similar to the BN1 afternoon event, $R_{\mathrm{GF}}$ was unaffected by the sudden change in concentrations. This reinforces that $R_{\mathrm{GF}}$ did not exhibit responses to sudden changes in airmass at the BEACHON-ROCS site. Finally, rainfall at $\sim$ 19:00 caused a fast decrease in all VOC concentrations, 


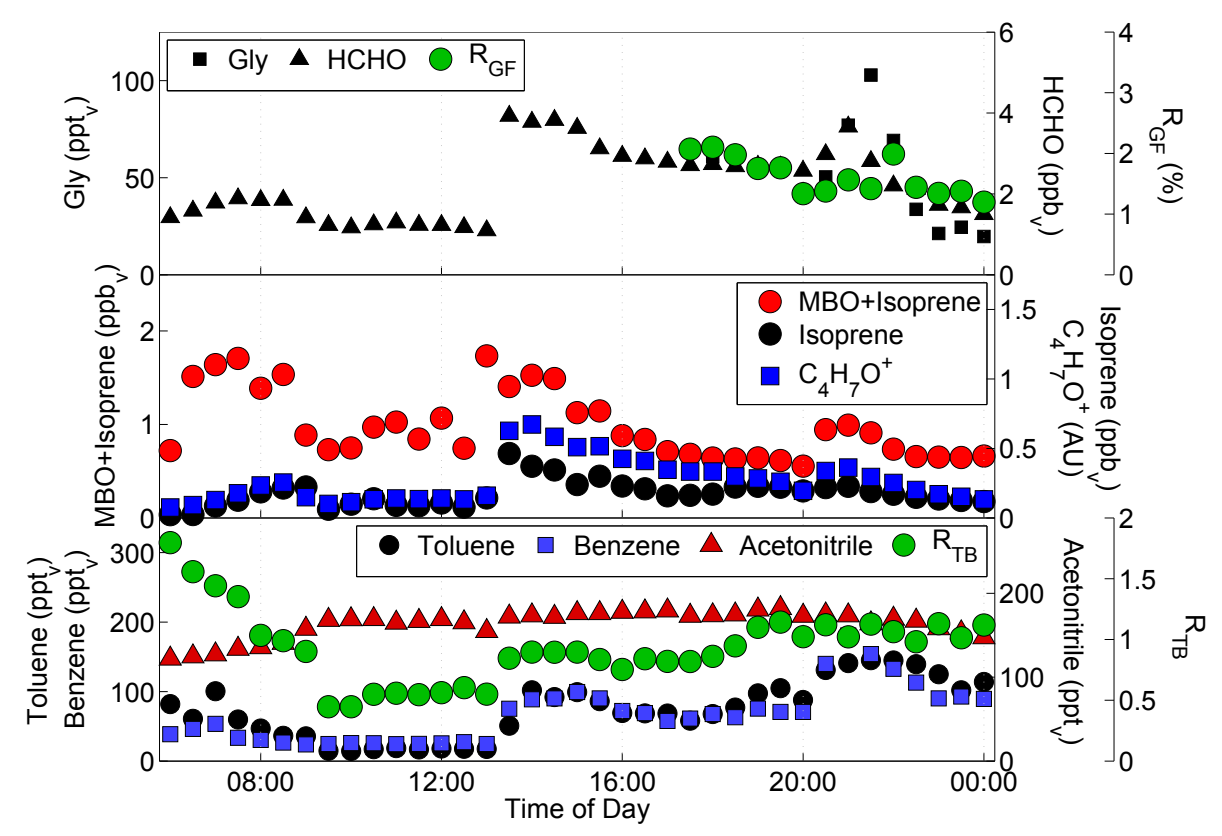

Fig. 5. Gly, $\mathrm{HCHO}, R_{\mathrm{GF}}$ and other tracer species during day BN3 (DOY 226). Gly, HCHO, and $R_{\mathrm{GF}}$ are shown as 30 min binned averages ( \pm 15 min each half hour), whereas other species are shown at full resolution. Data for MBO+Isoprene, $\mathrm{C}_{4} \mathrm{H}_{7} \mathrm{O}^{+}$, benzene, and acetonitrile were measured via PTR-TOF-MS. Data shown for toluene was measured via TOGA, and $\mathrm{R}_{\mathrm{TB}}$ is based on TOGA measurements of benzene and toluene.

including Gly, $\mathrm{HCHO}$, and $\mathrm{C}_{4} \mathrm{H}_{7} \mathrm{O}^{+}$. $R_{\mathrm{GF}}$ remained surprisingly constant during this transition, given the large differences in gas/liquid partitioning between Gly and HCHO (Ip et al., 2009; Staudinger and Roberts, 1996).

\subsection{BEACHON-ROCS 14 August 2010 (BN3)}

During the BN1 and BN2 afternoon events, we observed no change in $R_{\mathrm{GF}}$ despite sharp increases in Gly, HCHO, and benzene. However, benzene concentrations remained fairly low, especially compared to the MFI events. During the day BN3 (14 August; Figs. 5, S10, S12d), the morning and afternoon had similar behavior as during BN1 and BN2, but the evening exhibited different behavior as it was the only time substantially increased $R_{\mathrm{GF}}$ values were observed. Unfortunately, Gly measurements did not start until early evening of this day, but the various other measured species indicate that the site was undergoing a similar change in airmass in the afternoon as during the $\mathrm{BN} 1$ and $\mathrm{BN} 2$ afternoon events.

As during the BN1 morning event, during the morning of $\mathrm{BN} 3$, OVOC concentrations (including $\mathrm{HCHO}$ ) exhibited a sudden decrease (BN3 morning event), suggesting a transition to a less/differently photochemically-processed airmass. VOC concentrations remained mostly level until a wind direction change at $\sim 13: 15$, when $\mathrm{HCHO}, \mathrm{MBO}+$ Isoprene, and $\mathrm{C}_{4} \mathrm{H}_{7} \mathrm{O}^{+}$concentrations rose quickly, whereas acetonitrile stayed constant, referred to as the BN3 afternoon event. Benzene, toluene, and many alkanes (butane, isopentane, pentane) rose significantly. The ratio of toluene:benzene, a measure of the processing of anthropogenic air, also increased substantially $(\sim 50 \%)$ at this time, though recent measurements have suggested that this use of the ratio of toluene:benzene may be affected by non-negligible biogenic toluene sources (White et al., 2009). Still, the combination of increases in alkane concentrations and the ratio of toluene:benzene confirms that anthropogenic VOCs in this new airmass were less/differently processed than the previous airmass. Isoprene also shows a marked increase at this time. As this rise was quite similar to the rise in BN1, it is likely that there was a similar spike in isoprene during BN1 as well, though measurements are not available to confirm this.

Of particular interest is the region from $\sim$ 19:00 to $\sim 23: 00$ (see Fig. 6), referred to as the BN3 evening event. Both $\mathrm{HCHO}$ and Gly exhibited a series of brief $(\sim 2-5 \mathrm{~min})$ spikes in concentration. Even more significant was that for the only time during either of the campaigns discussed in this work, $R_{\mathrm{GF}}$ also increased significantly over these short timescales, yielding the largest values of $R_{\mathrm{GF}}$ during both campaigns and approaching values observed in urban areas. At the same time, we observed strongly increased benzene and toluene concentrations, including the highest benzene concentrations during BEACHON-ROCS, a slight rise in both $\mathrm{MBO}+$ Isoprene concentrations and $\mathrm{C}_{4} \mathrm{H}_{7} \mathrm{O}^{+}$with no observable change in acetonitrile concentrations. The strongly-elevated benzene with constant acetonitrile indicates that these spikes were caused by relatively fresh and strong anthropogenic influence. This is further supported by 


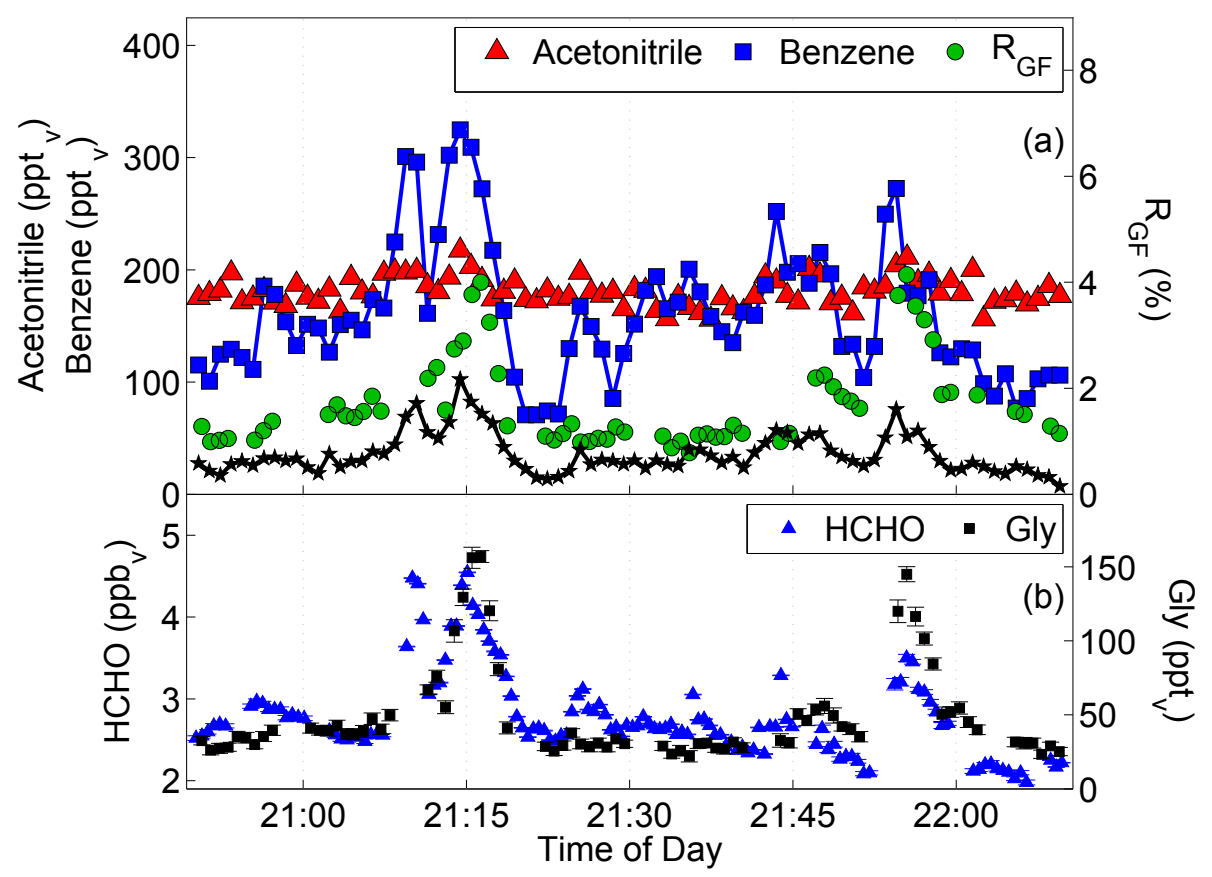

Fig. 6. A closer view of sharp changes in (a) benzene, acetonitrile, and $\mathrm{C}_{6} \mathrm{H}_{7} \mathrm{O}^{+}$concentrations and $R_{\mathrm{GF}}$ and (b) $\mathrm{HCHO}$ and Gly during day BN3 (DOY 226). $\mathrm{C}_{6} \mathrm{H}_{7} \mathrm{O}^{+}$is attributed to phenol and is expressed in arbitrary units (AU). Data is shown at maximum resolution, and no binning was employed. The evening event shown is the only instance during $\mathrm{HCHO}$ and Gly measurement of greater than $0.65 \mathrm{AU} \mathrm{C}_{6} \mathrm{H}_{7} \mathrm{O}^{+}$, which was typically less than $0.2 \mathrm{AU}$. Error bars are shown for $\mathrm{HCHO}$ and Gly, denoting $1 \sigma$ precision.
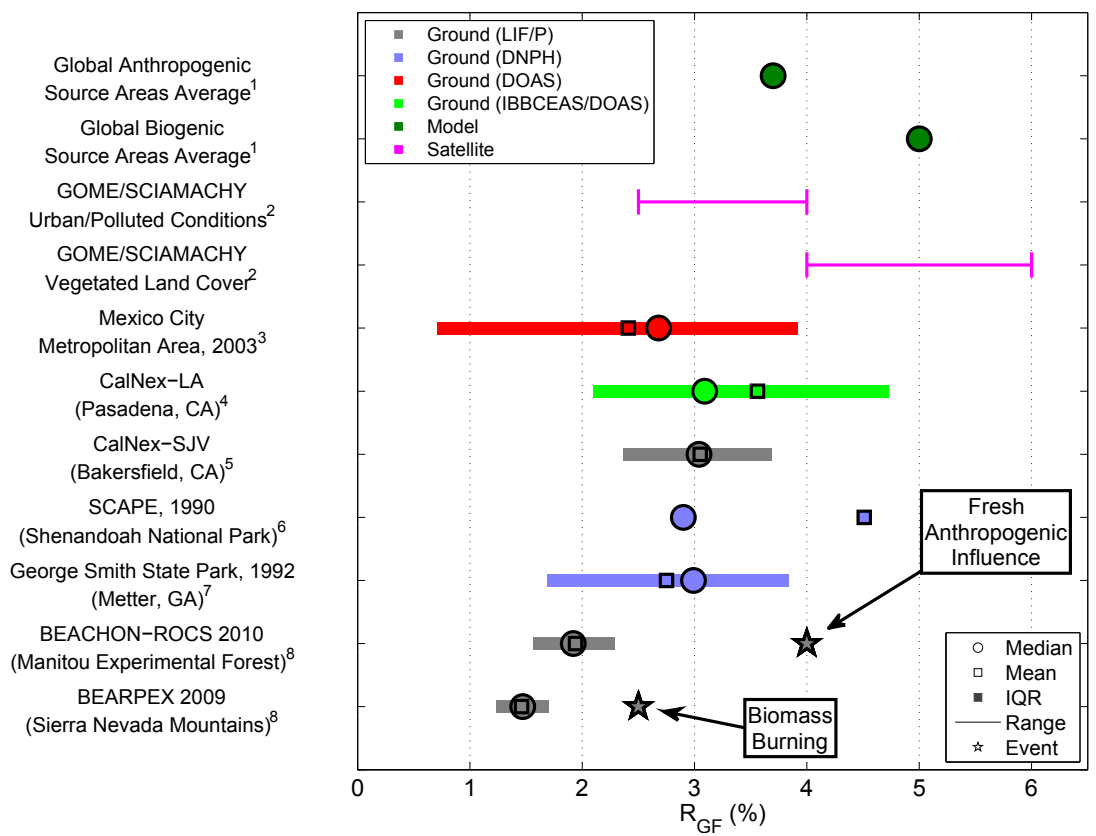

Fig. 7. $R_{\mathrm{GF}}$ ranges during campaigns presented in this work and the literature. Circles denote the campaign medians, the squares denote the campaign means, and the lines denote the interquartile range (middle 50\%) of the datasets. Stars denote biomass burning (MFI) and fresh anthropogenic (BN3) events during the campaigns discussed in this work. ${ }^{1}$ Myriokefalitakis et al. (2008); ${ }^{2}$ Vrekoussis et al. (2010); Folkard Wittrock, personal communication (2012); ${ }^{3}$ Volkamer et al. (2005); ${ }^{4}$ Gly: Washenfelder et al. (2011); HCHO: Warneke et al. (2011); ${ }^{5}$ Henry et al. (2012); ${ }^{6}$ Munger et al. (1995); ${ }^{7}$ Lee et al. (1995), estimated from data in Fig. $8 ;{ }^{8}$ this work. 
measurements of $\mathrm{C}_{6} \mathrm{H}_{7} \mathrm{O}^{+}$, which is attributed to phenol. Phenol has a much shorter lifetime than toluene and the BN3 evening event was the only event for which we observed deviation of $\mathrm{C}_{6} \mathrm{H}_{7} \mathrm{O}^{+}$from background levels (Fig. S11), indicating fresh anthropogenic influence. At the same time, we observed the only deviation and fast change in $R_{\mathrm{GF}}$ for the entire campaign. The spikes during the BN3 evening event are distinct evidence that fresh anthropogenic air (i.e. with reactive anthropogenic VOCs) has higher $R_{\mathrm{GF}}$, a trend opposite of that predicted by satellites (see Sect. 4.1).

\section{Discussion}

The observation of changes in reactive VOC composition between BVOCs and biomass burning/AVOCs on a very short timescale affords the opportunity to evaluate trends in $R_{\mathrm{GF}}$ without potential instrumental changes, such as changes in calibration factors. The results from BEARPEX 2009 and BEACHON-ROCS demonstrate that $R_{\mathrm{GF}}$ is a tracer sensitive to the reactive VOC composition of the measured air mass. $R_{\mathrm{GF}}$ was observed to be distinctly elevated for the oxidation of high concentrations of anthropogenic VOCs and conditionally elevated for biomass-burning plumes, compared to the lower $R_{\mathrm{GF}}$ values for oxidation of reactive BVOCs. Therefore, $R_{\mathrm{GF}}$ may represent a useful metric for the degree of reactive anthropogenic or biomass burning influence on rural areas via transport of reactive anthropogenic VOCs or biomass burning plumes. As $R_{\mathrm{GF}}$ did not vary even for large and rapid changes in absolute concentrations of Gly and $\mathrm{HCHO}, R_{\mathrm{GF}}$ appears insensitive to the extent/type of oxidative processing of air masses with similar reactive VOC composition. In the following sections, we discuss the extent of agreement between surface and satellite retrievals of $R_{\mathrm{GF}}$ and the origin of the observed large changes reported in this study in absolute Gly and HCHO concentrations at constant $R_{\mathrm{GF}}$ (i.e. constant reactive VOC composition).

\subsection{Gly: HCHO ratios from anthropogenic and biogenic VOC oxidation: surface and satellite values}

Figure 7 shows a comparison between $R_{\mathrm{GF}}$ in this work and the literature. Our measurements during BEACHONROCS and BEARPEX 2009 typically had low values of $R_{\mathrm{GF}}(<2 \%)$. Sites in urban areas such as the Mexico City Metropolitan Area (Garcia et al., 2006), Pasadena, CA (Washenfelder et al., 2011), and Bakersfield, CA (Henry et al., 2012) typically exhibited higher values of $R_{\mathrm{GF}}(2.5-$ $3.5 \%$ ). This trend of increased $R_{\mathrm{GF}}$ in air masses with anthropogenic influence matches with observations for the transport events during BEACHON-ROCS. Specifically, the BN3 event reached $R_{\mathrm{GF}}$ values up to $4 \%$. In contrast to surface-based measurements, $R_{\mathrm{GF}}$ values based on GOME and SCIAMACHY satellite retrievals have been observed to be lower $(<4 \%)$ in urban/polluted areas as compared to rural areas (4-6\%) with vegetated land cover (Vrekoussis et al., 2010). Satellite-driven global models tend to agree with these satellite retrievals (Myriokefalitakis et al., 2008). Median daytime $R_{\mathrm{GF}}$ during BEACHON-ROCS and BEARPEX as measured on the ground were less than $30 \%$ of those retrieved by satellites in rural regions. We believe this is not an LIF/LIP instrumental artifact, as $R_{\mathrm{GF}}$ measured using the same instrumentation in Bakersfield, CA were consistent with other urban field sites (Henry et al., 2012). Furthermore, the trend of higher $R_{\mathrm{GF}}$ values for anthropogenic VOC mixtures over the very short timescales of individual events during these campaigns is independent of instrumental changes (i.e. calibration factors) and even the absolute value of $R_{\mathrm{GF}}$.

The cause of the disagreement between surface measurements and satellite retrievals is unclear but may be partially explained by the inherent limitations of comparing a nearsurface point measurement with column-averaged satellite retrieval. In rural forests, there is evidence that direct emission may be a major source of $\mathrm{HCHO}$ within the forest canopy (DiGangi et al., 2011) and may result in significantly lower $R_{\mathrm{GF}}$ near the canopy. However, these emissions are too small to be significant on the scale of the boundary layer and would only result in decreased $R_{\mathrm{GF}}$ at night when turbulence is low. Another possibility is that boundary layer ratios are overall significantly lower than free tropospheric ratios. However, the majority of the number densities of HCHO and Gly are expected to be in the boundary layer. Thus, the satellite retrievals should be strongly influenced by boundary layer values, although this depends on the altitude sensitivity for the satellite retrievals. The validity of this hypothesis is difficult to ascertain, as there have been no published simultaneous measurements of Gly and $\mathrm{HCHO}$ in the free troposphere. Finally, BVOC emissions at the BEARPEX 2009 and BEACHON-ROCS sites are dominated by MBO and monoterpene emissions, in contrast to isoprene-dominated deciduous forests (e.g. the Amazon, Northern Michigan) (Karl et al., 2007; Ortega et al., 2007). Although models indicate that $\mathrm{MBO}$ oxidation should yield higher $R_{\mathrm{GF}}$, Gly and $\mathrm{HCHO}$ yields in low- $\mathrm{NO}_{\mathrm{x}}$ high-isoprene environments are poorly understood. Even if measurements at these sites are shown to exhibit higher $R_{\mathrm{GF}}$, this study still indicates a larger degree in the variability of biogenic $R_{\mathrm{GF}}$ than is currently derived from satellite retrievals.

In addition to differences in absolute values in $R_{\mathrm{GF}}$ between urban and rural sites, there are significant differences in variability. As mentioned in Sect. 3, BEACHON-ROCS and BEARPEX overall exhibited very consistent $R_{\mathrm{GF}}$. However, urban ground sites report considerably higher variance. One potential explanation for these differences is the variability in reactive VOC mixture resulting from influence by different emission sources among these sites. Gly and HCHO concentrations at the BEACHON-ROCS and BEARPEX sites are generally determined by local BVOC emissions (MBO, MT, isoprene). In urban areas (e.g. Mexico City, Pasadena, and Bakersfield), the VOC mix is much 


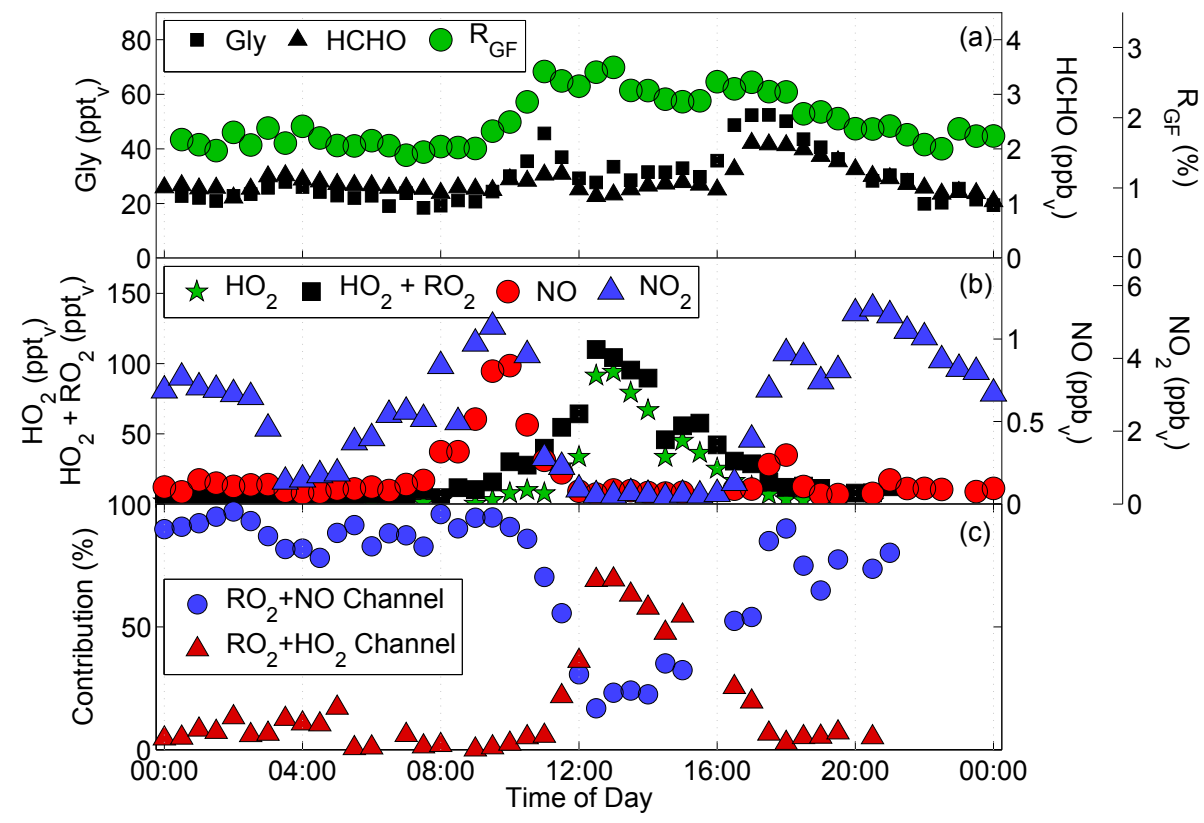

Fig. 8. Examination of $\mathrm{RO}_{2}$ fate and its relation to HCHO, Gly, and $R_{\mathrm{GF}}$ on 24 August during BEACHON-ROCS. (a \& b) Thirty minute binned medians of $R_{\mathrm{GF}}$ and concentrations of Gly, $\mathrm{HCHO}, \mathrm{NO}, \mathrm{NO}_{2}, \mathrm{HO}_{2}$, and $\mathrm{HO}_{2}+\mathrm{RO}_{2}$ over the course of the day. (c) Thirty minute binned medians of the percent of $\mathrm{RO}_{2}$ loss from reaction with $\mathrm{NO}$ or $\mathrm{HO}_{2}$ based on concentrations in (b) and rate constants from the IUPAC database.

more diverse, comprised of a mixture of advected BVOC and freshly-emitted anthropogenic VOCs. As different VOCs have different rates and yields of Gly and $\mathrm{HCHO}$ production, a fast-changing mix of VOCs, as would be expected in an urban setting, could result in a widely variable $R_{\mathrm{GF}}$. Traditionally, primary emissions of HCHO have been considered anthropogenic in nature (Garcia et al., 2006) and variability in these primary emissions certainly contributes to the observed urban variability in $R_{\mathrm{GF}}$. Recent evidence suggests that primary biogenic HCHO sources may be significant (DiGangi et al., 2011) which would lower $R_{\mathrm{GF}}$ in rural settings. Interestingly, sites at rural locations such as George Smith State Park, GA (Lee et al., 1995) and Shenandoah National Park, VA (Munger et al., 1995) have been reported to have $R_{\mathrm{GF}}$ similar in variability and typical values to urban areas. This is potentially due to the greater anthropogenic influence near these Southeastern US field sites, compared to sparser population nearer the Western US sites. The variable $R_{\mathrm{GF}}$ values for the George Smith State Park and Shenandoah National Park sites imply that these sites may experience greater anthropogenic VOC influence than the more remote BEARPEX and BEACHON-ROCS sites. However, it should be noted that the DNPH measurement technique used by these investigators can be prone to interferences and requires averaging over a long time (Arnts and Tejada, 1989; Kleindienst et al., 1998).

\subsection{Anthropogenic influence on BVOC oxidation via NO}

One of the most striking features in the BEACHON-ROCS $R_{\mathrm{GF}}$ is the lack of a change during quite significant (even $>100 \%$ ) changes in Gly and HCHO except during fresh anthropogenic VOC influence. Additionally, overall BVOC (MBO+Isoprene) concentrations typically do not significantly change $(\sim 12 \%)$ during these events. As BVOC concentrations do not change while oxidation products do, this suggests a difference in the oxidation pathways. VOC oxidation often begins by reaction with $\mathrm{OH}$, creating an $\mathrm{RO}_{2}$ radical, which can react with either $\mathrm{NO}, \mathrm{HO}_{2}$, another $\mathrm{RO}_{2}$, or itself. These differing channels result in different OVOC products, and lower NO concentrations in rural areas will naturally result in a lower yield of $\mathrm{RO}_{2}+\mathrm{NO}$ reaction products. Most models predict lower yields of Gly and $\mathrm{HCHO}$ with decreasing $\mathrm{NO}$ (i.e. $\mathrm{RO}_{2}+\mathrm{HO}_{2}$ becomes increasingly dominant) (Galloway et al., 2012). The morning decreases of Gly and HCHO observed during BEACHON-ROCS are consistent with a transition from a higher NO regime to a lower NO regime, and the afternoon/evening increases are the opposite. $R_{\mathrm{GF}}$ does not change significantly during the fast increases and decreases of Gly and HCHO concentrations, which is consistent with the similarity of the Gly and $\mathrm{HCHO}$ dependence on NO during MBO and isoprene oxidation used in common chemical mechanisms (e.g. University of Leeds Master Chemical Mechanism) (Galloway et al., 2012). The available NO data, although limited in quantity 
and sensitivity, generally agrees with this hypothesis (campaign midday median: $\sim 100 \mathrm{pptv}$ ).

Figure 8 shows one such day during BEACHON-ROCS on 24 August for which the low morning $\mathrm{HCHO}$ and Gly concentrations correlate with low $\mathrm{NO}_{\mathrm{x}}$ and in particular low NO values between 40 and 70 pptv. Due to limitations of the data set the other events could not be compared nor could the $\mathrm{OH} / \mathrm{HO}_{2}$ ratio be further analyzed. Therefore, it is not clear how consistent this correlation was or whether the low $\mathrm{HCHO}$ and Gly concentrations are the result of low NO concentrations and not the result of air masses that have accumulated more oxidation products. The similar lifetime of MBO, isoprene and Gly make this less likely, but from the available dataset we can only conclude that the observed behavior is consistent with transitions between high and low NO conditions. To further characterize these events, measurements of the $\mathrm{RO}_{2}+\mathrm{HO}_{2}$ oxidation products (i.e. hydroperoxides) would be of significant importance, as these would be expected to increase relative to the $\mathrm{RO}_{2}+\mathrm{NO}$ products. For example, in Fig. $8 \mathrm{c}$, the $\mathrm{RO}_{2}+\mathrm{HO}_{2}$ channel changes from $>70 \%$ to $<10 \%$ during the low NO to high NO transition, as calculated from $\mathrm{NO}$ and $\mathrm{HO}_{2}$ concentrations and rate constants from the IUPAC database.

\section{Conclusions}

In this work, we present the first simultaneous online measurements of Gly and HCHO during the BEARPEX 2009 and BEACHON-ROCS field intensives. Gly and HCHO concentrations at both sites showed significant variability, while $R_{\mathrm{GF}}$ diurnal values were typically remarkably consistent and peaked at midday. A fast change of airmass during BEARPEX 2009 due to the Mammoth Fire Incident resulted in a near doubling of $R_{\mathrm{GF}}$, the only large and/or rapid change or deviation in $R_{\mathrm{GF}}$ from the diurnal cycle during that campaign. This demonstrates that biomass burning influence can result in higher $R_{\mathrm{GF}}$. Similarly, fast, large increases of a PTR-TOF-MS mass corresponding to phenol, a very shortlived anthropogenic tracer, during BEACHON-ROCS coincided with fast increases in $R_{\mathrm{GF}}$, suggesting that fresh anthropogenic air mass influence also results in higher $R_{\mathrm{GF}}$.

An increase in $R_{\mathrm{GF}}$ was not observed during multiple events of weaker anthropogenic influence, because the majority of the reactive VOCs in that airmass were still biogenic in nature. This is despite evidence that the $\mathrm{NO}_{\mathrm{x}}$ levels were substantially elevated, likely leading to a transition of chemical regime. $R_{\mathrm{GF}}$ was not observed to change during these events, despite very rapid increases in both Gly and HCHO. During these events, concentrations of BVOCs with comparable lifetimes to $\mathrm{HCHO}$ and Gly were usually constant, suggesting that the rise in Gly and HCHO, and other oxidation products, was more likely due to a shift in the fate of the $\mathrm{RO}_{2}$ radical from a low NO regime to a higher one. Measurements of low-NO oxidation products, such as hydroper- oxides, would confirm this effect. This likely illustrates a way in which anthropogenic influence can affect rural photochemistry by simply altering the pathway by which local VOC emissions are processed. Ozone production is sensitive to $\mathrm{NO}_{\mathrm{x}}$, and large differences in SOA yields have been reported between high and low $\mathrm{NO}_{\mathrm{x}}$ regimes (Chan et al., 2010; Lane et al., 2008; $\mathrm{Ng}$ et al., 2007). We propose that $R_{\mathrm{GF}}$ together with the absolute concentrations could be an important and useful metric of the biogenic versus anthropogenic origin of a reactive VOC mix as well as the NO regime. Coincident measurements of $R_{\mathrm{GF}}$ with a low NO chemistry tracer, such as hydroperoxides, are necessary to confirm this. $R_{\mathrm{GF}}$ as an additional metric for the reactive VOC processing in a given airmass has many uses. Studies in rural areas with enhanced ozone can use $R_{\mathrm{GF}}$ to help constrain the source of the processing causing the enhanced ozone, in terms of anthropogenic vs. biogenic VOC sources, which can help with mitigation strategies. For example, if $R_{\mathrm{GF}}$ remains constant during the arrival of an enhanced ozone airmass, then the source of the enhanced local ozone production rate is likely not due to the influence of advected VOCs, but a change in the chemical pathway by which the air is processed.

$R_{\mathrm{GF}}$ at these rural sites were observed to be typically lower than at any ground sites reported in the literature. Possible anthropogenic VOC influence at other rural sites may have contributed to higher ratios there, whereas other reports have been from urban campaigns, although measurements in other, isoprene dominated, rural areas are needed to confirm this. While ground-based urban campaigns are consistent with satellite column retrievals of urban areas, satellite retrievals show higher $R_{\mathrm{GF}}$ in areas with greater $\mathrm{BVOC}$ influence. The trend of increased $R_{\mathrm{GF}}$ from anthropogenic reactive VOC mixtures and biomass burning compared to biogenic reactive VOC mixtures from our work is robust due to the short timescales over which the observed changes in $R_{\mathrm{GF}}$ occurred. Similarly, observations in Bakersfield directly preceding the BEACHON-ROCS campaign with the same instrumentation gave higher $R_{\mathrm{GF}}$ values (Henry et al., 2012). The cause of this discrepancy between the ground and satellite retrievals is unclear. Considering the importance of satellite retrievals for global models, it is important to resolve this discrepancy through further studies, especially through studies of the vertical tropospheric distributions of Gly and $\mathrm{HCHO}$.

\section{Supplementary material related to this article is available online at: http://www.atmos-chem-phys.net/12/ 9529/2012/acp-12-9529-2012-supplement.pdf.}

Acknowledgements. The authors thank the National Science Foundation (ATM 0852406), the NCAR BEACHON project, NASA-SBIR Phase I \& II, Austrian Science Fund (FWF): [L518], and the Camille and Henry Dreyfus Foundation for support. We 
would also like to thank Rainer Volkamer, José García, Rebecca Washenfelder, Cora Young, Catalina Tsai, Jochen Stütz, Folkard Wittrock, and Andreas Richter for sharing data and for useful discussions. NCAR is sponsored by the National Science Foundation. Lisa Kaser is a recipient of a DOC-fFORTE-fellowship of the Austrian Academy of Sciences at the Institute of Ion Physics and Applied Physics.

Edited by: J. Williams

\section{References}

Andreae, M. O. and Merlet, P.: Emission of trace gases and aerosols from biomass burning, Global Biogeochem. Cy., 15, 955-966, 2001.

Apel, E. C., Hills, A. J., Lueb, R., Zindel, S., Eisele, S., and Riemer, D. D.: A fast-GC/MS system to measure C2 to C4 carbonyls and methanol aboard aircraft, J. Geophys. Res., 108, 8794, doi:10.1029/2002JD003199, 2003.

Apel, E. C., Emmons, L. K., Karl, T., Flocke, F., Hills, A. J., Madronich, S., Lee-Taylor, J., Fried, A., Weibring, P., Walega, J., Richter, D., Tie, X., Mauldin, L., Campos, T., Weinheimer, A., Knapp, D., Sive, B., Kleinman, L., Springston, S., Zaveri, R., Ortega, J., Voss, P., Blake, D., Baker, A., Warneke, C., Welsh-Bon, D., de Gouw, J., Zheng, J., Zhang, R., Rudolph, J., Junkermann, W., and Riemer, D. D.: Chemical evolution of volatile organic compounds in the outflow of the Mexico City Metropolitan area, Atmos. Chem. Phys., 10, 2353-2375, doi:10.5194/acp-10-23532010, 2010.

Arnts, R. R. and Tejada, S. B.: 2,4-Dinitrophenylhydrazine-coated silica gel cartridge method for determination of formaldehyde in air: identification of an ozone interference, Environ. Sci. Technol., 23, 1428-1430, 1989.

Atkinson, R.: Atmospheric chemistry of VOCs and $\mathrm{NO}_{\mathrm{x}}$, Atmos. Environ., 34, 2063-2101, 2000.

Chan, A. W. H., Galloway, M. M., Kwan, A. J., Chhabra, P. S., Keutsch, F. N., Wennberg, P. O., Flagan, R. C., and Seinfeld, J. H.: Photooxidation of 2-Methyl-3-Buten-2-ol (MBO) as a Potential Source of Secondary Organic Aerosol, Environ. Sci. Technol., 43, 4647-4652, 2009.

Chan, A. W. H., Chan, M. N., Surratt, J. D., Chhabra, P. S., Loza, C. L., Crounse, J. D., Yee, L. D., Flagan, R. C., Wennberg, P. O., and Seinfeld, J. H.: Role of aldehyde chemistry and NOx concentrations in secondary organic aerosol formation, Atmos. Chem. Phys., 10, 7169-7188, doi:10.5194/acp-10-7169-2010, 2010.

DiGangi, J.: Formaldehyde as a Probe of Rural Volatile Organic Compound Oxidation, Ph.d. thesis, University of Wisconsin, Madison, USA, 2012.

DiGangi, J. P., Boyle, E. S., Karl, T., Harley, P., Turnipseed, A., Kim, S., Cantrell, C., Maudlin III, R. L., Zheng, W., Flocke, F., Hall, S. R., Ullmann, K., Nakashima, Y., Paul, J. B., Wolfe, G. M., Desai, A. R., Kajii, Y., Guenther, A., and Keutsch, F. N.: First direct measurements of formaldehyde flux via eddy covariance: implications for missing in-canopy formaldehyde sources, Atmos. Chem. Phys., 11, 10565-10578, doi:10.5194/acp-1110565-2011, 2011.

Dillon, M. B., Lamanna, M. S., Schade, G. W., Goldstein, A. H., and Cohen, R. C.: Chemical evolution of the Sacramento urban plume: Transport and oxidation, J. Geophys. Res.-Atmos., 107, 4045, doi:10.1029/2001JD000969, 2002.

Dockery, D. W., Pope, C. A., Xu, X., Spengler, J. D., Ware, J. H., Fay, M. E., Ferris, B. G., and Speizer, F. E.: An Association between Air Pollution and Mortality in Six U.S. Cities, New England Journal of Medicine, 329, 1753-1759, 1993.

Draxler, R. and Rolph, G.: HYSPLIT (HYbrid Single-Particle Lagrangian Integrated Trajectory) Model access via NOAA ARL READY Website, 2011.

Dreyfus, G. B., Schade, G. W., and Goldstein, A. H.: Observational constraints on the contribution of isoprene oxidation to ozone production on the western slope of the Sierra Nevada, California, J. Geophys. Res.-Atmos., 107, 4365, 2002.

Fried, A., McKeen, S., Sewell, S., Harder, J., Henry, B., Goldan, P., Kuster, W., Williams, E., Baumann, K., Shetter, R., and Cantrell, C.: Photochemistry of formaldehyde during the 1993 Tropospheric OH Photochemistry Experiment, J. Geophys. Res.Atmospheres, 102, 6283-6296, 1997.

Fu, T.-M., Jacob, D. J., Wittrock, F., Burrows, J. P., Vrekoussis, M., and Henze, D. K.: Global budgets of atmospheric glyoxal and methylglyoxal, and implications for formation of secondary organic aerosols, J. Geophys. Res., 113, D15303, doi:10.1029/2007JD009505, 2008.

Galloway, M. M., DiGangi, J. P., Hottle, J. R., Huisman, A. J., Mielke, L. H., Alaghmand, M., Shepson, P. B.,Weremijewicz, J., Klavon, H., McNeal, F. M., Carroll, M. A., Griffith, S., Hansen, R. F., Stevens, P. S., Bertman, S. B., and Keutsch, F. N.: Observations and modeling of formaldehyde at the PROPHET mixed hardwood forest site in 2008, Atmos. Environ., 43, 403-410, doi:10.1016/j.atmosenv.2011.09.053, 2012.

Galloway, M. M., Huisman, A. J., Yee, L. D., Chan, A. W. H., Loza, C. L., Seinfeld, J. H., and Keutsch, F. N.: Yields of oxidized volatile organic compounds during the $\mathrm{OH}$ radical initiated oxidation of isoprene, methyl vinyl ketone, and methacrolein under high- $\mathrm{NO}_{\mathrm{x}}$ conditions, Atmos. Chem. Phys., 11, 10779-10790, doi:10.5194/acp-11-10779-2011, $2011 \mathrm{~b}$.

Garcia, A. R., Volkamer, R., Molina, L. T., Molina, M. J., Samuelson, J., Mellqvist, J., Galle, B., Herndon, S. C., and Kolb, C. E.: Separation of emitted and photochemical formaldehyde in Mexico City using a statistical analysis and a new pair of gas-phase tracers, Atmos. Chem. Phys., 6, 4545-4557, doi:10.5194/acp-64545-2006, 2006.

Goldstein, A. H., Hultman, N. E., Fracheboud, J. M., Bauer, M. R., Panek, J. A., Xu, M., Qi, Y., Guenther, A. B., and Baugh, W.: Effects of climate variability on the carbon dioxide, water, and sensible heat fluxes above a ponderosa pine plantation in the Sierra Nevada (CA), Agr. Forest Meteorol., 101, 113-129, 2000.

Graus, M., Muller, M., and Hansel, A.: High Resolution PTR-TOF: Quantification and Formula Confirmation of VOC in Real Time, J. Am. Soc. Mass Spectrom., 21, 1037-1044, 2010.

Hays, M. D., Geron, C. D., Linna, K. J., Smith, N. D., and Schauer, J. J.: Speciation of Gas-Phase and Fine Particle Emissions from Burning of Foliar Fuels, Environ. Sci. Technol., 36, 2281-2295, 2002.

Henry, S. B., DiGangi, J. P., Weber, R. J., Gentner, D. R., Goldstein, A. H., and Keutsch, F. N.: Formaldehyde influences from combustion and photochemistry at a California urban site, in preparation, 2012. 
Holzinger, R., Warneke, C., Hansel, A., Jordan, A., Lindinger, W., Scharffe, D. H., Schade, G., and Crutzen, P. J.: Biomass burning as a source of formaldehyde, acetaldehyde, methanol, acetone, acetonitrile, and hydrogen cyanide, Geophys. Res. Lett., 26, 1161-1164, 1999.

Holzinger, R., Williams, J., Salisbury, G., Klüpfel, T., de Reus, M., Traub, M., Crutzen, P. J., and Lelieveld, J.: Oxygenated compounds in aged biomass burning plumes over the Eastern Mediterranean: evidence for strong secondary production of methanol and acetone, Atmos. Chem. Phys., 5, 39-46, doi:10.5194/acp-5-39-2005, 2005.

Hornbrook, R. S., Blake, D. R., Diskin, G. S., Fried, A., Fuelberg, H. E., Meinardi, S., Mikoviny, T., Richter, D., Sachse, G. W., Vay, S. A., Walega, J., Weibring, P., Weinheimer, A. J., Wiedinmyer, C., Wisthaler, A., Hills, A., Riemer, D. D., and Apel, E. C.: Observations of nonmethane organic compounds during ARCTAS - Part 1: Biomass burning emissions and plume enhancements, Atmos. Chem. Phys., 11, 11103-11130, doi:10.5194/acp11-11103-2011, 2011a.

Hornbrook, R. S., Crawford, J. H., Edwards, G. D., Goyea, O., Mauldin, R. L., Olson, J. S., and Cantrell, C. A.: Measurements of tropospheric $\mathrm{HO}_{2}$ and $\mathrm{RO}_{2}$ by oxygen dilution modulation and chemical ionization mass spectrometry, Atmos. Meas. Tech., 4, 735-756, doi:10.5194/amt-4-735-2011, $2011 \mathrm{~b}$.

Hottle, J. R., Huisman, A. J., Digangi, J. P., Kammrath, A., Galloway, M. M., Coens, K. L., and Keutsch, F. N.: A Laser Induced Fluorescence-Based Instrument for In-Situ Measurements of Atmospheric Formaldehyde, Environ. Sci. Technol., 43, 790-795, 2009.

Huisman, A. J., Hottle, J. R., Coens, K. L., DiGangi, J. P., Galloway, M. M., Kammrath, A., and Keutsch, F. N.: Laser-induced phosphorescence for the in situ detection of glyoxal at part per trillion mixing ratios, Analyt. Chem., 80, 5884-5891, 2008.

Huisman, A. J., Hottle, J. R., Galloway, M. M., DiGangi, J. P., Coens, K. L., Choi, W., Faloona, I. C., Gilman, J. B., Kuster, W. C., de Gouw, J., Bouvier-Brown, N. C., Goldstein, A. H., LaFranchi, B. W., Cohen, R. C., Wolfe, G. M., Thornton, J. A., Docherty, K. S., Farmer, D. K., Cubison, M. J., Jimenez, J. L., Mao, J., Brune, W. H., and Keutsch, F. N.: Photochemical modeling of glyoxal at a rural site: observations and analysis from BEARPEX 2007, Atmos. Chem. Phys., 11, 8883-8897, doi:10.5194/acp-118883-2011, 2011.

Ip, H. S. S., Huang, X. H. H., and Yu, J. Z.: Effective Henry's law constants of glyoxal, glyoxylic acid, and glycolic acid, Geophys. Res. Lett., 36, L01802, doi:10.1029/2008GL036212, 2009.

Jenkin, M. E., Saunders, S. M., Derwent, R. G., and Pilling, M. J.: Construction and application of a master chemical mechanism (MCM) for modelling tropospheric chemistry., Abstr. Pap. Am. Chem. Soc., 214, 116-COLL, 1997.

Jordan, A., Haidacher, S., Hanel, G., Hartungen, E., Märk, L., Seehauser, H., Schottkowsky, R., Sulzer, P., and Märk, T. D.: A high resolution and high sensitivity proton-transfer-reaction time-offlight mass spectrometer (PTR-TOF-MS), Int. J. Mass Spectrom., 286, 122-128, 2009.

Karl, T., Guenther, A., Yokelson, R. J., Greenberg, J., Potosnak, M., Blake, D. R., and Artaxo, P.: The tropical forest and fire emissions experiment: Emission, chemistry, and transport of biogenic volatile organic compounds in the lower atmosphere over Amazonia, J. Geophys. Res., 112, D18302,
doi:10.1029/2007JD008539, 2007.

Kaser, L., DiGangi, J., Schnitzhofer, R., Herdlinger-Blatt, I., Karl, T., Graus, M., Turnipseed, A., Keutsch, F. N., and Hansel, A.: Intercomparison of Formaldehyde Measurements during BEACHON ROCS 2010, Atmos. Chem. Phys. Discuss., submitted, 2012.

Khalil, M. A. K. and Rasmussen, R. A.: Carbon-Monoxide in the Earth's Atmosphere - Indications of a Global Increase, Nature, 332, 242-245, 1988.

Kim, S., Karl, T., Guenther, A., Tyndall, G., Orlando, J., Harley, P., Rasmussen, R., and Apel, E.: Emissions and ambient distributions of Biogenic Volatile Organic Compounds (BVOC) in a ponderosa pine ecosystem: interpretation of PTR-MS mass spectra, Atmos. Chem. Phys., 10, 1759-1771, doi:10.5194/acp-101759-2010, 2010.

Kleindienst, T. E., Corse, E. W., Blanchard, F. T., and Lonneman, W. A.: Evaluation of the Performance of DNPH-Coated Silica Gel and C18 Cartridges in the Measurement of Formaldehyde in the Presence and Absence of Ozone, Environ. Sci. Technol., 32, 124-130, 1998.

Koppmann, R., von Czapiewski, K., and Reid, J. S.: A review of biomass burning emissions, part I: gaseous emissions of carbon monoxide, methane, volatile organic compounds, and nitrogen containing compounds, Atmos. Chem. Phys. Discuss., 5, 1045510516, doi:10.5194/acpd-5-10455-2005, 2005.

Laden, F., Neas, L. M., Dockery, D. W., and Schwartz, J.: Association of fine particulate matter from different sources with daily mortality in six US cities, Environ. Health Persp., 108, 941-947, 2000.

Lane, T. E., Donahue, N. M., and Pandis, S. N.: Effect of $\mathrm{NO}_{\mathrm{x}}$ on secondary organic aerosol concentrations, Environ. Sci. Technol., 42, 6022-6027, 2008.

Lee, Y. N., Zhou, X. L., and Hallock, K.: Atmospheric carbonyl compounds at a rural southeastern United States site, J. Geophys. Res.-Atmos., 100, 25933-25944, 1995.

Lee, Y. N., Zhou, X., Kleinman, L. I., Nunnermacker, L. J., Springston, S. R., Daum, P. H., Newman, L., Keigley, W. G., Holdren, M. W., Spicer, C. W., Young, V., Fu, B., Parrish, D. D., Holloway, J., Williams, J., Roberts, J. M., Ryerson, T. B., and Fehsenfeld, F. C.: Atmospheric chemistry and distribution of formaldehyde and several multioxygenated carbonyl compounds during the 1995 Nashville Middle Tennessee Ozone Study, J. Geophys. Res.-Atmos., 103, 22449-22462, 1998.

Luecken, D. J., Hutzell, W. T., Strum, M. L., and Pouliot, G. A.: Regional sources of atmospheric formaldehyde and acetaldehyde, and implications for atmospheric modeling, Atmos. Environ., 47, 477-490, 2012.

Mauldin, R. L., Tanner, D. J., and Eisele, F. L.: Measurements of OH during PEM-Tropics A, J. Geophys. Res.-Atmospheres, 104, 5817-5827, 1999.

Mauzerall, D. L. and Wang, X. P.: Protecting agricultural crops from the effects of tropospheric ozone exposure: Reconciling science and standard setting in the United States, Europe, and Asia, Ann. Rev. Energ. Environ., 26, 237-268, 2001.

McDonald, J. D., Zielinska, B., Fujita, E. M., Sagebiel, J. C., Chow, J. C., and Watson, J. G.: Fine Particle and Gaseous Emission Rates from Residential Wood Combustion, Environ. Sci. Technol., 34, 2080-2091, 2000. 
Müller, M., Graus, M., Ruuskanen, T. M., Schnitzhofer, R., Bamberger, I., Kaser, L., Titzmann, T., Hörtnagl, L., Wohlfahrt, G., Karl, T., and Hansel, A.: First eddy covariance flux measurements by PTR-TOF, Atmos. Meas. Tech., 3, 387-395, doi:10.5194/amt-3-387-2010, 2010.

Munger, J. W., Jacob, D. J., Daube, B. C., Horowitz, L. W., Keene, W. C., and Heikes, B. G.: Formaldehyde, Glyoxal, and Methylglyoxal in Air and Cloudwater at a Rural Mountain Site in Central Virginia, J. Geophys. Res.-Atmos., 100, 9325-9333, 1995.

Myriokefalitakis, S., Vrekoussis, M., Tsigaridis, K., Wittrock, F., Richter, A., Bruhl, C., Volkamer, R., Burrows, J. P., and Kanakidou, M.: The influence of natural and anthropogenic secondary sources on the glyoxal global distribution, Atmos. Chem. Phys., 8, 4965-4981, doi:10.5194/acp-8-4965-2008, 2008.

Ng, N. L., Chhabra, P. S., Chan, A. W. H., Surratt, J. D., Kroll, J. H., Kwan, A. J., McCabe, D. C., Wennberg, P. O., Sorooshian, A., Murphy, S. M., Dalleska, N. F., Flagan, R. C., and Seinfeld, J. H.: Effect of NOx level on secondary organic aerosol (SOA) formation from the photooxidation of terpenes, Atmos. Chem. Phys., 7, 5159-5174, doi:10.5194/acp-7-5159-2007, 2007.

Ortega, J., Helmig, D., Guenther, A., Harley, P., Pressley, S., and Vogel, C.: Flux estimates and $\mathrm{OH}$ reaction potential of reactive biogenic volatile organic compounds (BVOCs) from a mixed northern hardwood forest, Atmos. Environ., 41, 5479-5495, 2007.

Ostro, B.: The Association of Air-Pollution and Mortality - Examining the Case for Inference, Arch. Environ. Health, 48, 336-342, 1993.

Rolph, G.: Real-time Environmental Applications and Display sYstem (READY) Website, 2011.

Ruuskanen, T. M., Müller, M., Schnitzhofer, R., Karl, T., Graus, M., Bamberger, I., Hörtnagl, L., Brilli, F., Wohlfahrt, G., and Hansel, A.: Eddy covariance VOC emission and deposition fluxes above grassland using PTR-TOF, Atmos. Chem. Phys., 11, 611-625, doi:10.5194/acp-11-611-2011, 2011.

Saunders, S. M., Jenkin, M. E., Derwent, R. G., and Pilling, M. J.: Protocol for the development of the Master Chemical Mechanism, MCM v3 (Part A): tropospheric degradation of nonaromatic volatile organic compounds, Atmos. Chem. Phys., 3, 161-180, doi:10.5194/acp-3-161-2003, 2003.

Staudinger, J. and Roberts, P. V.: A critical review of Henry's law constants for environmental applications, Crit. Rev. Environ. Sci. Technol., 26, 205-297, 1996.

Stieb, D. M., Beveridge, R. C., Brook, J. R., Smith-Doiron, M. A. R. C., Burnett, R. T., Dales, R. E., Beaulieu, S., Judek, S., and Mamedov, A.: Air pollution, aeroallergens and cardiorespiratory emergency department visits in Saint John, Canada, J. Exp. Anal. Environ. Epidemiol., 10, 461-477, 2000.

Tan, D., Faloona, I., Simpas, J. B., Brune, W., Shepson, P. B., Couch, T. L., Sumner, A. L., Carroll, M. A., Thornberry, T., Apel, E., Riemer, D., and Stockwell, W.: $\mathrm{HO}_{\mathrm{x}}$ budgets in a deciduous forest: Results from the PROPHET summer 1998 campaign, J. Geophys. Res.-Atmos., 106, 24407-24427, 2001.
Volkamer, R., Molina, L. T., Molina, M. J., Shirley, T., and Brune, W. H.: DOAS measurement of glyoxal as an indicator for fast VOC chemistry in urban air, Geophys. Res. Lett., 32, L08806, doi:10.1029/2005GL022616, 2005.

Vrekoussis, M., Wittrock, F., Richter, A., and Burrows, J. P.: Temporal and spatial variability of glyoxal as observed from space, Atmos. Chem. Phys., 9, 4485-4504, doi:10.5194/acp-9-44852009, 2009.

Vrekoussis, M., Wittrock, F., Richter, A., and Burrows, J. P.: GOME-2 observations of oxygenated VOCs: what can we learn from the ratio glyoxal to formaldehyde on a global scale?, Atmos. Chem. Phys., 10, 10145-10160, doi:10.5194/acp-1010145-2010, 2010.

Warneke, C., Veres, P., Holloway, J. S., Stutz, J., Tsai, C., Alvarez, S., Rappenglueck, B., Fehsenfeld, F. C., Graus, M., Gilman, J. B., and de Gouw, J. A.: Airborne formaldehyde measurements using PTR-MS: calibration, humidity dependence, intercomparison and initial results, Atmos. Meas. Tech., 4, 23452358, doi:10.5194/amt-4-2345-2011, 2011.

Washenfelder, R. A., Young, C. J., Brown, S. S., Angevine, W. M., Atlas, E. L., Blake, D. R., Bon, D. M., Cubison, M. J., de Gouw, J. A., Dusanter, S., Flynn, J., Gilman, J. B., Graus, M., Griffith, S., Grossberg, N., Hayes, P. L., Jimenez, J. L., Kuster, W. C., Lefer, B. L., Pollack, I. B., Ryerson, T. B., Stark, H., Stevens, P. S., and Trainer, M. K.: The glyoxal budget and its contribution to organic aerosol for Los Angeles, California, during CalNex 2010, J. Geophys. Res.-Atmos., 116, D00V02, doi:10.1029/2011JD016314, 2011.

White, M. L., Russo, R. S., Zhou, Y., Ambrose, J. L., Haase, K., Frinak, E. K., Varner, R. K., Wingenter, O. W., Mao, H., Talbot, R., and Sive, B. C.: Are biogenic emissions a significant source of summertime atmospheric toluene in the rural Northeastern United States?, Atmos. Chem. Phys., 9, 81-92, doi:10.5194/acp9-81-2009, 2009.

Wittrock, F., Richter, A., Oetjen, H., Burrows, J. P., Kanakidou, M., Myriokefalitakis, S., Volkamer, R., Beirle, S., Platt, U., and Wagner, T.: Simultaneous global observations of glyoxal and formaldehyde from space, Geophys. Res. Lett., 33 L16804, doi:10.1029/2006GL026310, 2006.

Wolfe, G. M. and Thornton, J. A.: The Chemistry of AtmosphereForest Exchange (CAFE) Model - Part 1: Model description and characterization, Atmos. Chem. Phys., 11, 77-101, doi:10.5194/acp-11-77-2011, 2011. 